\title{
Satellite radar altimetry for monitoring small rivers and lakes in Indonesia
}

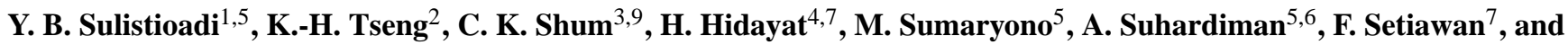 \\ S. Sunarso $^{8}$ \\ ${ }^{1}$ Hydrological Sciences Laboratory, NASA Goddard Space Flight Center, Greenbelt, MD, USA \\ ${ }^{2}$ Center of Space \& Remote Sensing Research, National Central University, Taoyuan, Taiwan \\ ${ }^{3}$ Division of Geodetic Science, School of Earth Sciences, the Ohio State University, Columbus, OH, USA \\ ${ }^{4}$ Hydrology and Quantitative Water Management Group, Wageningen University, Wageningen, the Netherlands \\ ${ }^{5}$ Department of Forest Science, University of Mulawarman, Samarinda, Indonesia \\ ${ }^{6}$ Department of Global Agricultural Sciences, the University of Tokyo, Tokyo, Japan \\ ${ }^{7}$ Research Center for Limnology, Indonesian Institute of Sciences, Cibinong, Indonesia \\ ${ }^{8}$ PT Vale Indonesia, Tbk, Sorowako, Indonesia \\ ${ }^{9}$ Institute of Geodesy and Geophysics, Chinese Academy of Sciences, Wuhan, China
}

Correspondence to: Y. B. Sulistioadi (y.b.sulistioadi@nasa.gov)

Received: 17 January 2014 - Published in Hydrol. Earth Syst. Sci. Discuss.: 10 March 2014

Revised: 22 October 2014 - Accepted: 4 November 2014 - Published: 19 January 2015

\begin{abstract}
Remote sensing and satellite geodetic observations are capable of hydrologic monitoring of freshwater resources. Although satellite radar altimetry has been used in monitoring water level or discharge, its use is often limited to monitoring large rivers ( $>1 \mathrm{~km}$ ) with longer interval periods ( $>1$ week) because of its low temporal and spatial resolutions (i.e., satellite revisit period). Several studies have reported successful retrieval of water levels for small rivers as narrow as $40 \mathrm{~m}$. However, processing current satellite altimetry signals for such small water bodies to retrieve water levels accurately remains challenging. Physically, the radar signal returned by water bodies smaller than the satellite footprint is most likely contaminated by non-water surfaces, which may degrade the measurement quality. In order to address this scientific challenge, we carefully selected the waveform shapes corresponding to the range measurement resulting from standard retrackers for the European Space Agency's (ESA's) Envisat (Environmental Satellite) radar altimetry. We applied this approach to small (40-200 $\mathrm{m}$ in width) and medium-sized (200-800 $\mathrm{m}$ in width) rivers and small lakes (extent $<1000 \mathrm{~km}^{2}$ ) in the humid tropics of Southeast Asia, specifically in Indonesia. This is the first study that explored the ability of satellite altimetry to monitor small water bodies in Indonesia.
\end{abstract}

The major challenges in this study include the size of the water bodies that are much smaller than the nominal extent of the Envisat satellite footprint (e.g., $\sim 250 \mathrm{~m}$ compared to $\sim 1.7 \mathrm{~km}$, respectively) and slightly smaller than the alongtrack distance (i.e., $\sim 370 \mathrm{~m}$ ). We addressed this challenge by optimally using geospatial information and optical remote sensing data to define the water bodies accurately, thus minimizing the probability of non-water contamination in the altimetry measurement. Considering that satellite altimetry processing may vary with different geographical regions, meteorological conditions, or hydrologic dynamic, we further evaluated the performance of all four Envisat standard retracking procedures.

We found that satellite altimetry provided a good alternative or the only means in some regions of measuring the water level of medium-sized rivers and small lakes with high accuracy (root mean square error (RMSE) of $0.21-0.69 \mathrm{~m}$ and a correlation coefficient of $0.94-0.97)$. In contrast to previous studies, we found that the commonly used Ice-1 retracking algorithm was not necessarily the best retracker among the four standard waveform retracking algorithms for Envisat radar altimetry observing inland water bodies. As a recommendation, we propose to include the identification and selection of standard waveform shapes to complete the use of 
standard waveform retracking algorithms for Envisat radar altimetry data over small and medium-sized rivers and small lakes.

\section{Introduction}

A number of small to medium-sized rivers are poorly gauged (Alsdorf and Lettenmaier, 2003). Small rivers are defined as those with $40-200 \mathrm{~m}$ in width and $10-100 \mathrm{~m}^{3} \mathrm{~s}^{-1}$ average discharge, while medium rivers are defined as those with $200-800 \mathrm{~m}$ in width and $100-1000 \mathrm{~m}^{3} \mathrm{~s}^{-1}$ average discharge (Meybeck et al., 1996). The installation and operation of in situ measurement such as permanent gauging is costly and not a priority for developing countries such as Indonesia. However, there is an increasing interest in continuous satellite-based monitoring of hydrologic bodies, including narrow or small rivers. Therefore, with the absence of continuously operating in situ measurements, it is a scientific and social challenge to develop a complementary water resource monitoring system with water level and discharge as the essential variables.

Space geodesy and satellite remote sensing are viable sources of observation to complement or replace in situ measured data that are lacking or unavailable. A number of researchers have demonstrated the ability of remote sensing to measure hydrological variables (Tang et al., 2009). Initiatives to develop a global river and lake water level database exist to date, but none of them accounts for small to medium-sized rivers and lakes in the humid tropics.

Satellite altimetry missions were initially aimed to support oceanographic studies (Brown and Cheney, 1983). However, scientists were able to use altimetry data to retrieve the water surface elevation of large rivers and lakes. These studies include those utilizing early satellite altimetry missions (Wingham and Rapley, 1987; Koblinsky et al., 1993; Morris and Gill, 1994), as well as recent ones (e.g., Birkett, 1998; Benveniste and Defrenne, 2003; Kouraev et al., 2004; Calmant and Seyler, 2006; Frappart et al., 2006; Cretaux et al., 2011).

The application of satellite altimetry to monitor inland waters has several limitations. The long satellite repeat cycle makes the satellite potentially miss important hydrological events (e.g., flash flood) between the repeats. For instance, the repeat period for TOPEX/Poseidon and Jason-1/2 is 10 days, 35 days for ERS-1/2, Envisat and SARAL/Altika, and 91 days for ICESat. The low spatial resolution of the radar altimeter, as represented by the radar altimeter footprint (about 1.7 to $3 \mathrm{~km}$ for calm waters), limits the measurement only to wide rivers, due to interference of the returned radar signal by non-water features. Earlier studies showed that satellite radar altimetry was useful for monitoring large rivers with widths greater than $1 \mathrm{~km}$ (Birkett, 1998; Birkett et al., 2002). However, recent studies demonstrated successful retrieval of water levels of small rivers $(<100 \mathrm{~m}$ width) (Kuo and Kao, 2011; Michailovsky et al., 2012). Nonetheless, the processing of satellite altimetry measurement for small water bodies remains challenging because of its spatial and temporal limitations.

Early studies of satellite altimetry to retrieve water levels of a river used waveform shapes to match the specular characteristics that exclusively belong to the signals returned by the river (Koblinsky et al., 1993). "Specular" refers to a reflection characteristic where a signal reflects in one direction, thus matching the reflection by a mirror (e.g., Torrance and Sparrow, 1967). In the context of radar signal processing, this occurs when the radar signal hits a calm or smooth water surface, which is represented as a peak in the return signal power (e.g., as represented by a power spectrum). Along with this principle, scientists developed non-ocean retrackers in the last decade. These include the offset center of gravity (OCOG) or Ice-1 (Wingham et al., 1986), the volume scattering retracker (Davis, 1997), the Sea Ice retracker (Laxon, 1994), the NASA B retracker (Zwally, 1996), the surface/threshold retracker (Davis, 1997) and Ice-2 (Legresy and Remy, 1997). The offset center of gravity (OCOG) or Ice-1 (Wingham et al., 1986) is a simple but robust retracker that only requires the statistics of the waveform samples and does not require any model (model-free retracker) (Bamber, 1994). The Ice-2 algorithm modifies the Ocean retracker (Brown, 1977) by adding a scattering distribution coefficient that describes the vertical profile of the reflecting surfaces. This coefficient accounts for the interference of the default scattering pattern as generated by snow, ice sheets, sand or vegetation (Legresy and Remy, 1997). Laxon (1994) introduced the Sea Ice algorithm specifically to study sea ice elevation by (1) characterizing the power and shapes of the radar return, (2) classifying the sea ice and determining the waveform parameters, and (3) correcting the retracked range. Ice1 , Ice-2 and Sea Ice along with the Ocean retracker (that is exclusively developed for ocean studies) were the standard retrackers for the European Space Agency (ESA)'s Envisat (Environmental Satellite) until the satellite was decommissioned in June 2012. Recent developments of inland water retracking methods include the improvements to the threshold retracker (Davis, 1997) by Lee (2008) and Bao et al. (2009), sub-waveform analysis (e.g., Hwang et al., 2006; FenoglioMarc et al., 2009) and sub-waveform filtering and track offset correction (Tseng, 2012).

For inland water studies of rivers and lakes, Frappart et al. (2006) found Ice-1 to be the best retracker for large rivers (e.g., the Amazon River) over the other standard retrackers for Envisat (i.e., Ocean, Ice-2 and Sea Ice). None of these retrackers is specifically developed for inland waters. Satellite altimetry processing also varies depending on geographical regions, meteorological conditions, and the hydrological dynamics of the water bodies. Up to this point, no "one size fits all" method for satellite altimetry waveform retracking is readily available to measure the water level of small (40- 


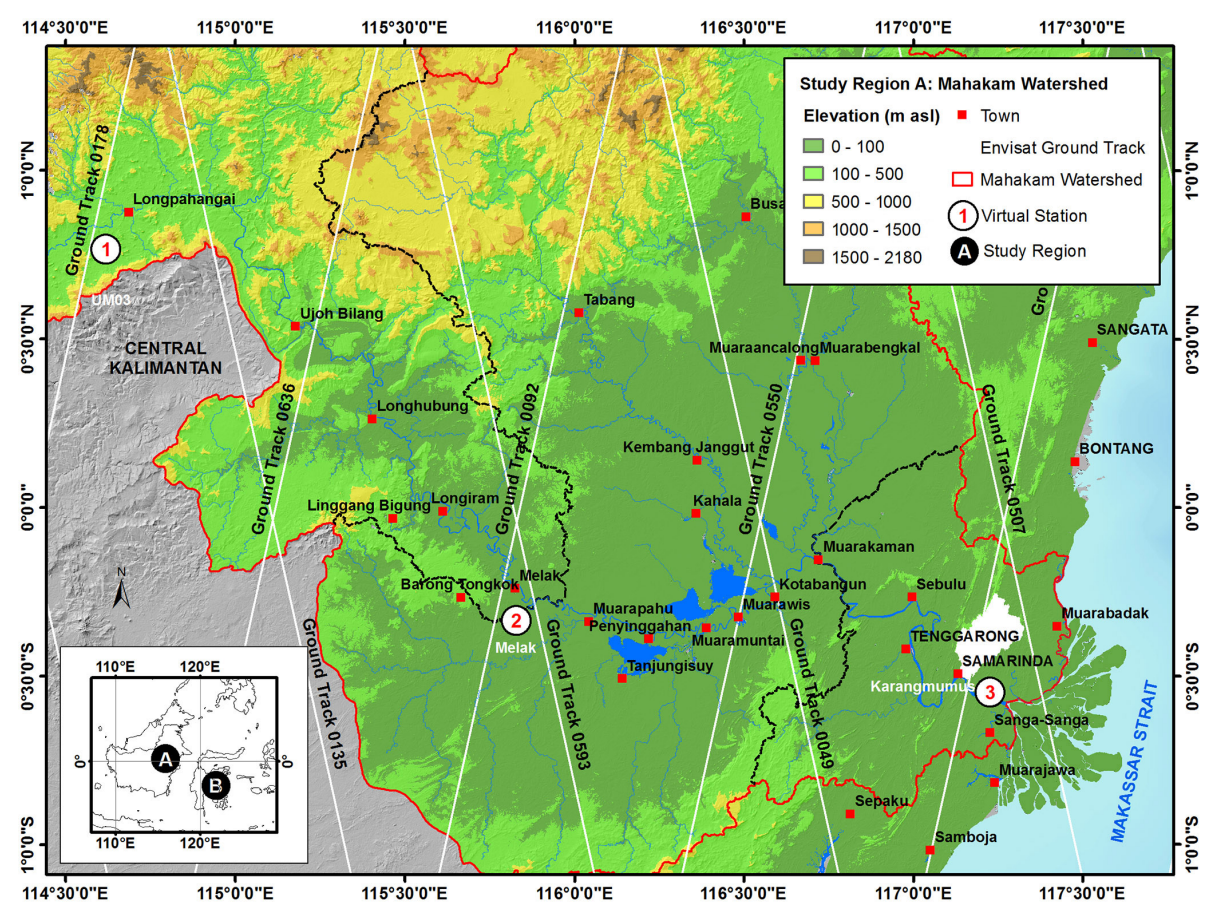

Figure 1. Study sites at the Mahakam watershed, East Kalimantan, Indonesia.

$200 \mathrm{~m}$ in width) and medium-sized (200-800 $\mathrm{m}$ in width) rivers and lakes. Hence, there is a need to develop a specific algorithm or additional procedures for satellite altimetry applications to study inland waters. Furthermore, there is also a need to evaluate the commonly used Ice-1-based retracker in different regions of interest.

Since the size of the water bodies is smaller than the satellite footprint, the surrounding non-water surface often contaminates the satellite altimetry's returned radar signal. In this study, we solved this issue by integrating geospatial information and optical remote sensing with satellite altimetry measurement to monitor small water bodies. Our study indicates that careful demarcation of water bodies reduces the contamination of a return radar signal caused by the presence of a non-water surface, thus improving the quality of the measurement.

In this study, we processed the results of Envisat standard waveform retracking procedures (Ocean, Ice-1, Ice-2 and Sea Ice) to monitor the water level of a small river, a medium river and two lakes in the tropics. In addition to the standard waveform retracking procedures, we performed careful spatial and waveform shape selection and outlier detection to screen out low-quality data. We then evaluated the results against in situ measured water levels to assess their accuracy.

\section{Study area}

This study was conducted in the following water bodies in Indonesia (Figs. 1 and 2): the Mahakam and Karangmumus rivers in East Kalimantan Province (Borneo Island), and Lake Matano and Lake Towuti in South Sulawesi Province (Sulawesi Island). The Karangmumus River is a tributary downstream of the Mahakam River, while Lake Matano and Lake Towuti are part of the Malili lake complex. These water bodies represent different geomorphology, climate and anthropogenic situations, as described below.

\subsection{Mahakam and Karangmumus rivers}

The Mahakam watershed is located at $113^{\circ} 40^{\prime}$ to $117^{\circ} 30^{\prime} \mathrm{E}$ longitude and $1^{\circ} 00^{\prime} \mathrm{S}$ to $1^{\circ} 45^{\prime} \mathrm{N}$ latitude. Mahakam is the second largest river in the country, which stretches to $\sim 920 \mathrm{~km}$ and drains an area of $77095 \mathrm{~km}^{2}$. The Mahakam River rises in the mountainous forest ranges with dramatic elevation drops in the first hundreds of kilometers of the main stem, where the formation of rolling hills and steep slopes forms the upstream part of this watershed. The middle Mahakam Lake and wetlands form up starting from about $500 \mathrm{~km}$ downstream from the headwater and transform into the Mahakam Delta estuary in the last hundred kilometers of the Mahakam River (MacKinnon et al., 1996). The upstream part of the Mahakam River has a narrow channel with $40-100 \mathrm{~m}$ in width, 5 to $10 \mathrm{~m}$ average depth, and a river bed slope greater than $2 \%$. Forest and small patches of subsidence farmlands dominate the land use of this upstream por- 


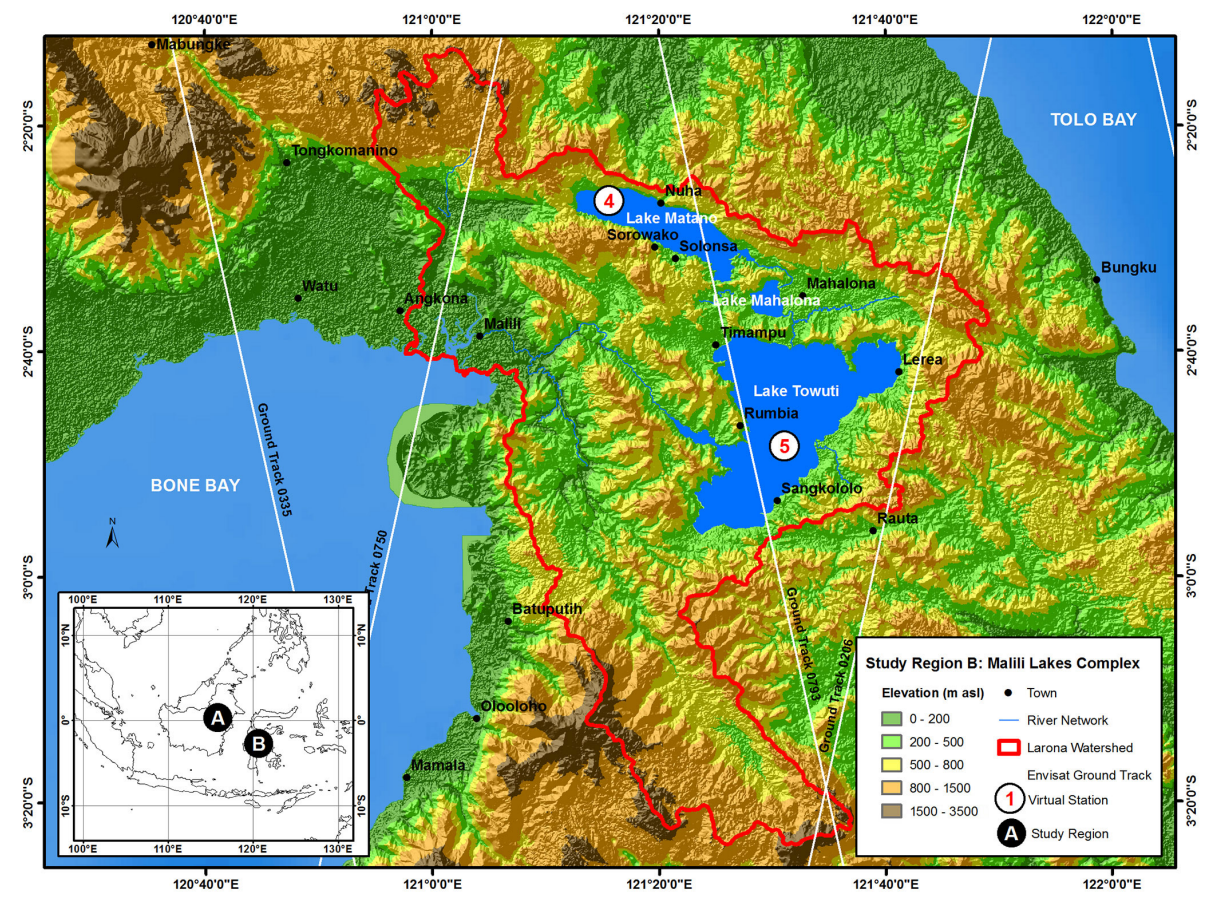

Figure 2. Study sites at the Malili lake complex, South Sulawesi, Indonesia.

tion. The middle part has a medium-sized channel with 100 $300 \mathrm{~m}$ in width, $10-24 \mathrm{~m}$ in depth and a $0.5-2 \%$ slope. Extensive lowland and agricultural areas spread about everywhere along with country-style residential areas, lakes and swampy shrubs. The lower part and the Mahakam Delta have a wide channel of 500-850 $\mathrm{m}$ in width, 10-24 $\mathrm{m}$ in depth and a $0-0.5 \%$ slope. The lower sub-watershed is typically a developed area with residential areas, scarce forest patches and heavily inhabited land (Estiaty et al., 2007).

The Karangmumus River is a narrow channel ( 3 to $45 \mathrm{~m}$ in width) that is an important waterway for the residents of Samarinda in East Kalimantan Province. The Karangmumus sub-watershed often experiences gradual increases and steady high water levels during simultaneous heavy rainfall and backwater intrusion from ocean tides through the Mahakam Delta.

\subsection{Lake Matano and Lake Towuti}

Lake Matano is located at $121^{\circ} 12^{\prime}$ to $121^{\circ} 29^{\prime} \mathrm{E}$ longitude and $2^{\circ} 23^{\prime}$ to $2^{\circ} 34^{\prime} \mathrm{N}$ latitude. This lake counts as the seventh deepest lake of the world (Herdendorf, 1982), despite its small extent $\left(164 \mathrm{~km}^{2}\right)$. With the maximum depth of $595 \mathrm{~m}$ and mean water surface elevation measured at $392 \mathrm{~m}$, Lake Matano represents a cryptodepression (i.e., the lake bed is below the mean sea level) (Hehanussa and Haryani, 1999). Originating by tectonic processes since $2-3$ million years ago, this lake is one of the oldest lakes of the world. The lake hosts endemic faunas that provide remarkable examples of ecological diversification and speciation (Cristescu et al.,
2010). The basins in the surrounding areas of Lake Matano are formed by the hardness of the rocks and the softness of a uplift tectonic fault that forms a limited number of alluvial plains. Lake Matano also has two flat depressions separated by a saddle. It drains through the Petea River into Lake Mahalona, which is located in the same Malili lake complex (Vaillant et al., 2011).

Lake Towuti is recognized as the largest tectonic lake in Indonesia (Russel and Bijaksana, 2012). Located at the downstream end of the Malili lake complex, this lake covers an extent of $562 \mathrm{~km}^{2}$ with $206 \mathrm{~m}$ depth. Similar to Lake Matano, Lake Towuti carries locally endemic fauna, since this lake is also one of the ancient lakes.

\section{Materials and methods}

\subsection{Envisat radar altimetry}

In this study we used satellite radar altimeter measurements from the European Space Agency (ESA)'s Envisat Radar Altimeter (RA-2) during the period of July 2002 to October 2010, corresponding to cycles 6 to 93 (ESA, 2007). The RA-2 determines the two-way delay of radar echo from the Earth's surface at a very high precision of less than a nanosecond. In addition, it measures the power and shape of the reflected radar pulses, which are represented by the waveforms. The RA-2 on-board signal processor calculates the average of approximately 100 measurements of individual echo burst at $\sim 1800 \mathrm{~Hz}$. These data, along with 
the waveforms, are averaged into the 18 measurements per second $(18 \mathrm{~Hz})$. The $18 \mathrm{~Hz}$ data correspond to an alongtrack sampling interval of $\sim 350 \mathrm{~m}$ (ESA, 2011). The averaged $18 \mathrm{~Hz}$ waveforms are arranged into 128 gates with 3.125 nanosecond temporal resolution, and presents the default tracking gate at \#46 (ESA, 2007). We also utilized the Envisat RA-2/Microwave Radiometer (MWR) Sensor Geophysical Data Record (SGDR) (hereafter, RA-2/MWR SGDR) Level-2 product. The RA-2/MWR SGDR contains parameters for time tagging, geo-location, output from retrackers (i.e., range, wind speed, significant wave height) at $1 \mathrm{~Hz}$, and other $18 \mathrm{~Hz}$ parameters such as range and orbital altitude. The RA-2/MWR SGDR also contains the $18 \mathrm{~Hz}$ waveforms that we used in the waveform shape selection procedure. We used the $18 \mathrm{~Hz}$ re-tracked range to infer the water surface elevation. Before comparing the altimetry with in situ measurements, we first corrected the instrumental (i.e., Doppler shift and oscillator drift), the geophysical (i.e., inverse barometer, polar and solid Earth tides) and the media (i.e., ionosphere and dry/wet troposphere) range in order to match the standard retracker range (Ocean, Ice-1, Ice-2 and Sea Ice) produced from the Level-2 radar altimeter product.

Satellite radar altimetry measures water surface elevation with respect to the reference ellipsoid. Due to the uncertainty in the relationship between the elevations of the field gauge benchmark relative to the local vertical datum, we used the water level anomaly in our analysis. The anomaly was calculated by subtracting the water level mean over the study period (July 2002-October 2010) from the observed level. Hence, it represents the fluctuation of a water level relative to its mean level. In order to test the current assumption of Ice-1 as the best retracking algorithm for inland waters (Frappart et al., 2006), we compared the water level anomaly obtained from water surface elevation measured by the Ocean, Ice-1, Ice-2 and Sea Ice retrackers with those obtained from the in situ gauge measurement.

\subsection{Optical remote sensing and geospatial data set}

We applied standard optical remote sensing data processing techniques in order to obtain imageries with a precise position and better contrast ratio between land and water. The processing included geometric correction, development and contrast adjustment of the pseudo-natural color composite imagery from a red-green-blue combination (bands 5, 4 and 3 of Landsat 5 and Landsat 7, or bands 6, 5 and 4 for the recently launched Landsat 8 ). We then measured river and lake width through visual interpretation of the remote sensing imagery (i.e., through the dark-blue color reflected by the water bodies in the pseudo-natural color composite of Landsat imagery) and marked the boundaries. When the object was too small to detect using visual inspection of remote sensing images, we used medium-scale (1:50000) topographic maps released by the Indonesian Geospatial Agency to identify and mark the boundary.

Previous work (Sarmiento and Khan, 2010) showed that satellite altimetry measurements were less accurate when the center of the satellite altimetry footprint was closer to the lakeshore. In order to test this hypothesis, we created masks with varying distances to the lakeshore (i.e., 0-500, 500-1000 and $>1000 \mathrm{~m}$ ). The footprint diameter of the Envisat RA-2 over a smooth surface is about $1.7 \mathrm{~km}$ (Rees, 1990; ESA, 2007). We assumed that the Envisat altimeter measurements within the last mask (i.e., $>1000 \mathrm{~m}$ from the lakeshore) were not influenced by the surrounding non-water surface. We then analyzed the performance of altimeter measurements based on these masks. As for the river, we created a mask with a $5 \mathrm{~m}$ buffer distance to the riverbank, in order to reduce the land surface-waveform contamination and to tolerate any geo-referencing and projection errors of the satellite imagery and topographic maps.

\subsection{In situ water level data}

Indonesia's Ministry of Public Works provided the data sets used for validation of water levels of the Mahakam River at the Melak site (2002-2004) and the Karangmumus River (2008-2010), while PT Vale Indonesia provided validation data for Lake Matano and Lake Towuti (2002-2012). Similar to the satellite altimetry data, we transformed the water level time series into a water level anomaly by removing the mean water surface elevation over the period of observation.

\subsection{Waveform shape analysis}

The presence of variable land cover (e.g., vegetation on the riverbank, lakeshore or coastline, as well as islands or sandbanks within the river or lake) affects the returned radar signal in altimetry measurement (e.g., Deng and Featherstone, 2006; Berry et al., 2005). Therefore, we analyzed the waveform shapes considering that the radar pulse reflected by the small water bodies might be influenced by other surfaces within the projected radar footprint. For the lakes, a $1 \mathrm{~km}$ distance to the lakeshore was sufficient, since the radius of the Envisat footprint (half of its diameter) is about $850 \mathrm{~m}$. However, this issue becomes more challenging for small and medium-sized rivers (40-800 $\mathrm{m}$ in width), rendering the waveform produced by the processed radar pulse return unpredictable.

Due to the fact that an inland water surface is smoother than the ocean (Birkett, 1998), we assumed that a (quasi)specular shape is the standard waveform shape for radar pulse returns reflected by inland water bodies, in contrast to the ocean-reflected diffuse shape (Koblinsky et al., 1993). Additional shapes of Envisat RA-2 returned radar pulses over inland water include (Berry et al., 2005) (i) a quasiBrown shape representing a transition from land to water, (ii) a flat-patch shape denoting an intermediate surface, and 

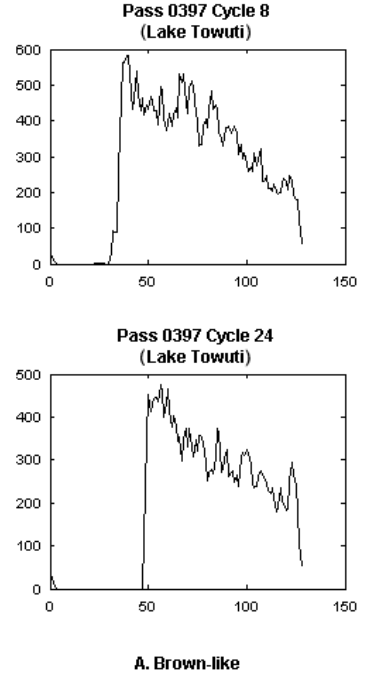
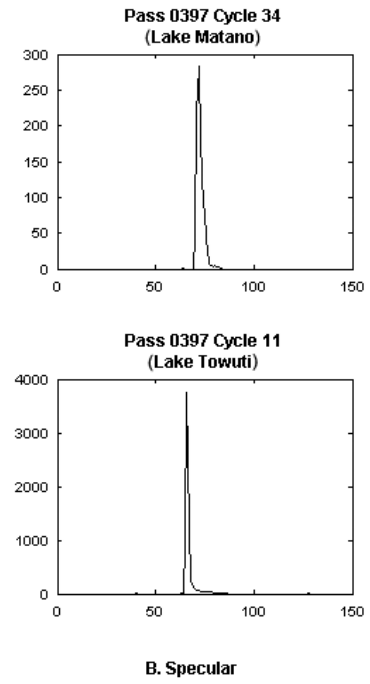
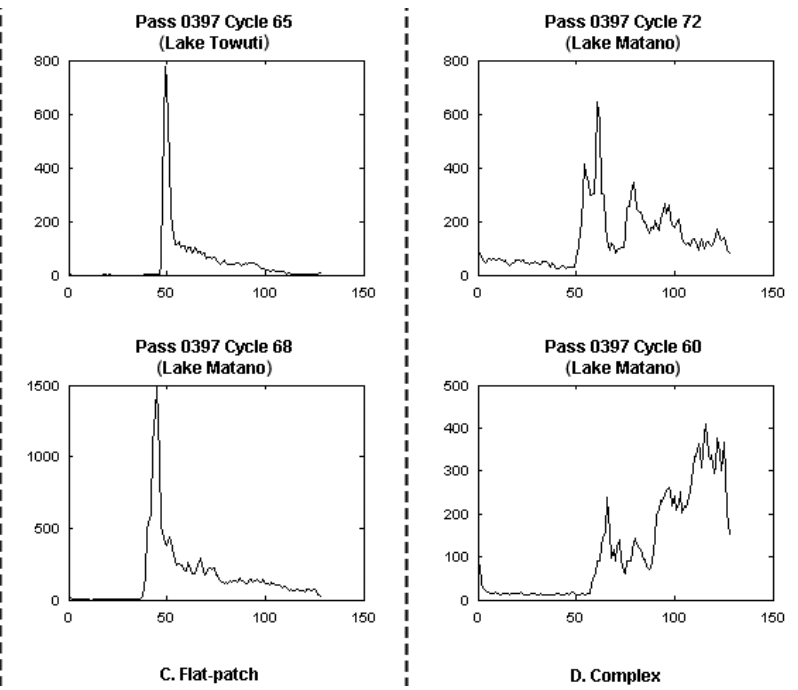

Figure 3. General categories of waveform shapes.

(iii) a complex shape indicating a mixture of water and vegetation (Dabo-Niang et al., 2007). In this study, we considered (quasi-)specular, quasi-Brown and flat-patch shapes as qualified waveforms to perform reliable range measurement and discard complex and non-classified shapes from further processing. We assumed that the mixture of water, vegetation and/or shoreline provides less accurate elevation measurements as compared to the radar signal returned by waterdominated surfaces. Some examples of actual waveforms that are classified as "Brown-like", specular, flat-patch, as well as complex and non-classified shapes, are presented in Fig. 3a-d, respectively. In practice, we displayed the standard waveform shapes (Brown-like, specular, flat-patch), with another window showing waveform shapes from each measurement along with their IDs. Then, we noted down the IDs of measurements that matched waveform shapes for further processing. It is interesting that, in order to select the most appropriate waveforms that are less contaminated by land surfaces, another study offered the highest weight for waveforms originating by water surfaces, and assigned a lower weight for waveforms reflected by other land surfaces (Michailovsky et al., 2012). Operationally, the implementation of straightforward waveform shape qualification as presented in this study offers slightly more efficient waveform processing, especially when the algorithm for waveform geometry processing can be developed.

\subsection{Outlier removal, validation and performance evaluation}

Although the altimetry measurements that carry nonqualified waveform shapes were excluded, some measurements remained far beyond the mean and median values. In order to obtain a data set with minimum influences from outliers, we excluded mild outliers - defined as any values out- side of 1.5 times the inter-quartile range (IQR) (Kenney and Keeping, 1947; Panik, 2012). IQR is defined as the range between the $25 \%$ quartile value $\left(Q_{0.25}\right)$ and the $75 \%$ quartile value $\left(Q_{0.75}\right)$. If we denoted $\mathrm{WSE}_{\min }$ and $\mathrm{WSE}_{\max }$ as the minimum and maximum water surface elevations from the Envisat radar altimetry, respectively, then

$$
\begin{array}{ll}
\mathrm{IQR}=Q_{0.75}-Q_{0.25} \text { therefore } & \mathrm{WSE}_{\min }=Q_{0.25}-1.5 \times \mathrm{IQR} \\
\mathrm{WSE}_{\max }=Q_{0.75}+1.5 \times \mathrm{IQR}
\end{array}
$$

Consequently, we discarded any measurements below the $\mathrm{WSE}_{\min }$ and above the $\mathrm{WSE}_{\max }$ threshold in further processing.

We used root mean square error (RMSE) and the coefficient of correlation $(r)$ as measures of performance (or validation) between satellite altimetry water level measurements and the virtual stations where in situ measurements were available. The RMSE is a measure of how far the estimated measures are from the "truth" values. It is defined as (e.g., Nagler, 2004; Li, 2010)

RMSE $=\sqrt{\sum_{i=1}^{n} \frac{\left(x_{i}-y_{i}\right)^{2}}{n}}$,

where $x_{i}$ is the Envisat water level anomaly and $y_{i}$ is the in situ measured water level anomaly.

The Pearson correlation coefficient is the standard measure of association for continuous types of data (de Sa, 2007). Therefore, we used it to measure the association between satellite altimetry and in situ water level measurements as described in the following equation:

$r=\frac{S_{x y}}{S_{x} S_{y}}$ with $S_{x y}=\sum_{i=1}^{n} \frac{\left(x_{i}-\bar{x}\right)\left(y_{i}-\bar{y}\right)}{(n-1)}$,

where $S_{x}$ and $S_{y}$ are variances for each sample and $n$ is the number of observations. The correlation coefficient $(r)$ value 


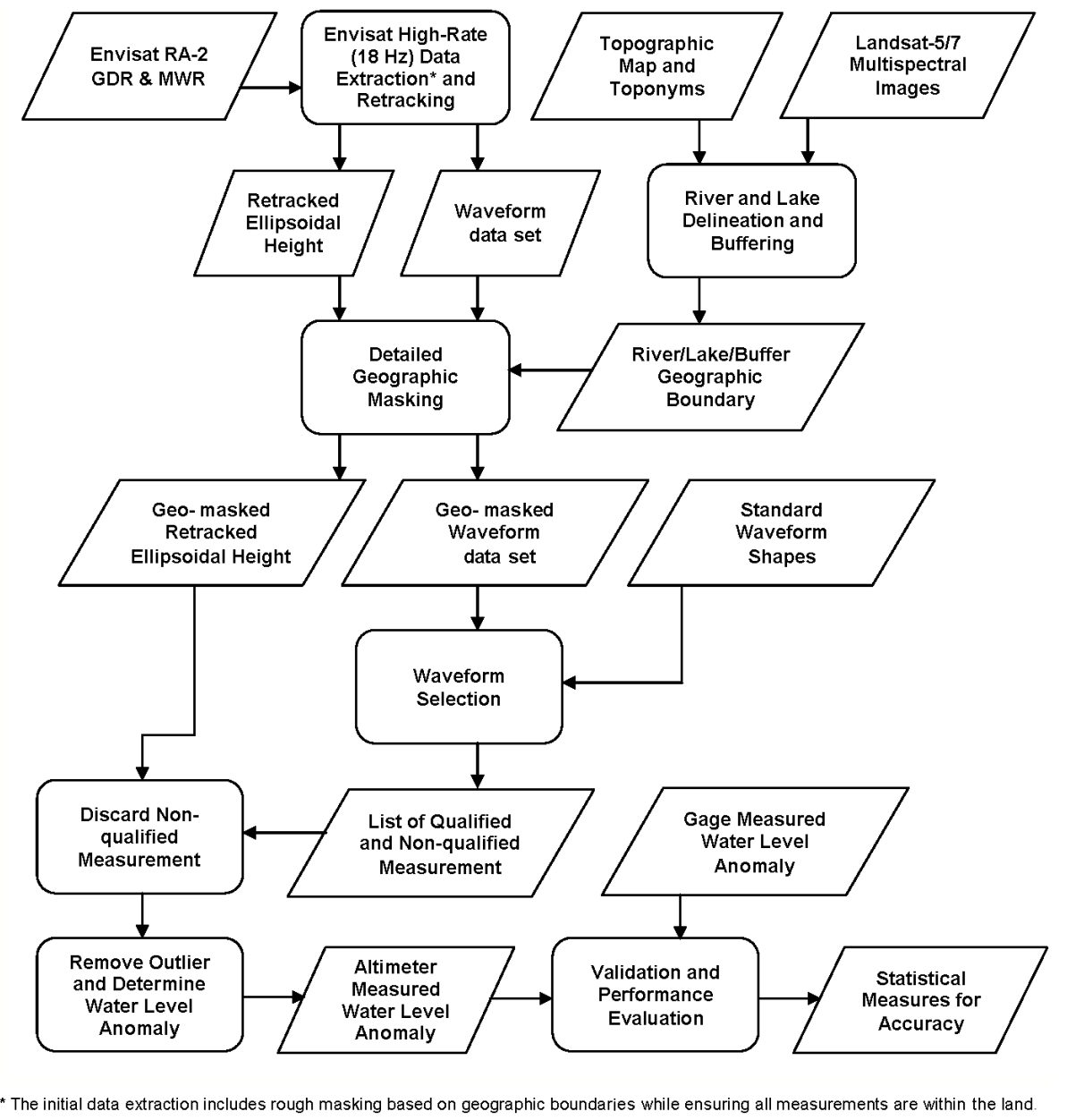

Figure 4. Data processing workflow.

falls within the interval $[-1,1]$, where a coefficient of 0 indicates no correlation between two measurements, +1 indicates the total correlation in the same direction (proportional relationship) and -1 indicates the total correlation in the opposite direction (inverse relationship).

In order to provide a comprehensive understanding of the data processing sequences in this study, Fig. 4 shows each data processing step and their relationships.

\section{Results and discussion}

\subsection{Mahakam and Karangmumus rivers}

Table 1 shows that most of the radar pulse returns from both small-sized rivers (40-200 $\mathrm{m}$ in width) and medium-sized rivers (200-800 $\mathrm{m}$ in width) produced qualified waveforms to infer water level fluctuation. The percentages of qualified waveforms relative to all measurements within the water bodies were high (90-97\%) even for a small river at virtual station UM03 (river width $54 \mathrm{~m}$ ). Interestingly, there were more missing cycles - regular satellite repeat schedule with- out available measurements within the water bodies - in the smaller river (UM03 site) than in the wider rivers (Melak01 and Melak02 sites).

For the water level measurements at Melak, we combined two virtual stations (i.e., Melak01 and Melak02), since they were just separated by a $14-40 \mathrm{~km}$ distance and there was no drastic change in the terrain and configuration of the channel (e.g., no reservoir or steep gradient) based on the topographic map and digital elevation model. Having two different satellite tracks nearby in fact increased the spatial and temporal sampling intensity for this location. Figure 5 shows the location of the Ministry of Public Works' gauge station, which was right in between these two virtual stations. Figure 5 also indicates dynamic channel morphology in this area. The channel was heavily meandering just before and along the Melak01 virtual station, which then changed into a $13 \mathrm{~km}$ straight channel along the heavily populated town of Melak before it was back to a lightly meandering channel. Figure 6 shows the combined water level anomaly from the two virtual stations, along with the water level anomaly observed by the gauge station for the period of 2002-2004. 
Table 1. The number of qualified and non-qualified altimeter measurements and outliers for study sites at Mahakam River.

\begin{tabular}{|c|c|c|c|c|c|c|c|c|c|}
\hline \multirow[t]{2}{*}{$\begin{array}{l}\text { Site } \\
\text { name }\end{array}$} & \multirow[t]{2}{*}{ Cycles } & \multirow{2}{*}{$\begin{array}{l}\text { No. of } \\
\text { missing } \\
\text { cycles }\end{array}$} & \multirow[t]{2}{*}{$\begin{array}{l}\text { Measurements } \\
\text { in water body }\end{array}$} & \multicolumn{2}{|c|}{$\begin{array}{c}\text { Qualified } \\
\text { measurement }\end{array}$} & \multicolumn{2}{|c|}{$\begin{array}{c}\text { Non-qualified } \\
\text { measurement }\end{array}$} & \multirow[t]{2}{*}{$\begin{array}{c}\text { No. of } \\
\text { outliers }\end{array}$} & \multirow{2}{*}{$\begin{array}{c}\text { River } \\
\text { width } \\
\text { (m) }\end{array}$} \\
\hline & & & & (No.) & $(\%)$ & (No.) & $(\%)$ & & \\
\hline UM03 & 9-93 & 34 & 51 & 46 & 90.2 & 5 & 9.8 & N/A & $54 \mathrm{~m}$ \\
\hline Melak01 & 7-93 & 8 & 225 & 220 & 97.8 & 5 & 2.2 & 8 & $247 \mathrm{~m}$ \\
\hline Melak02 & 7-93 & 11 & 148 & 134 & 90.5 & 14 & 9.5 & 0 & $294 \mathrm{~m}$ \\
\hline
\end{tabular}

Table 2. Performance evaluation of Envisat RA-2 radar altimetry measurements over Melak virtual stations at Mahakam River (width 247 m).

\begin{tabular}{lcccccc}
\hline $\begin{array}{l}\text { Site } \\
\text { name }\end{array}$ & $\begin{array}{c}\text { Cycles } \\
\text { covered }\end{array}$ & $\begin{array}{c}\text { Validated } \\
\text { measurements }\end{array}$ & $\begin{array}{c}\text { Number } \\
\text { of passes }\end{array}$ & Retracker & $\begin{array}{c}\text { RMSE } \\
(\mathrm{m})\end{array}$ & $\begin{array}{c}\text { Correlation } \\
\text { coefficient }\end{array}$ \\
\hline Melak & $7-33$ & 46 & 2 & Ocean & 0.885 & 0.955 \\
& & & & Ice-1 & 0.720 & 0.962 \\
& & & & Ice-2 & 0.724 & 0.966 \\
& & & Sea Ice & 0.685 & 0.970 \\
\hline
\end{tabular}

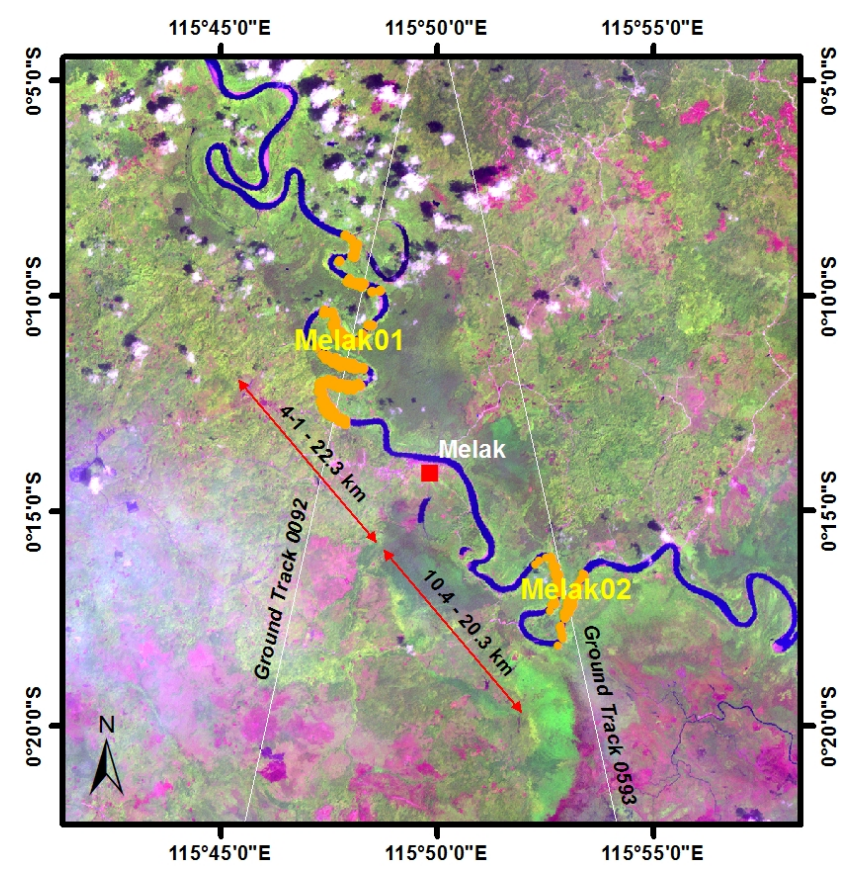

Figure 5. Location of Envisat virtual stations and in situ water level gauge stations at Melak.

To facilitate visual investigation, we presented scatter plots between the water level anomaly obtained from gauge measurements and those derived from the four different retracking algorithms. We found that Ice-1 was not the best retracking algorithm for inland water body elevation measurement (Table 2). The sea ice retracking algorithm outperformed the other three standard retrackers (Table 2). With a correlation coefficient of up to 0.97 , satellite radar altimetry was a more suitable alternative for monitoring of the medium-sized river
(200-800 $\mathrm{m}$ in width), even for a poorly gauged basin such as the Mahakam Watershed. Compared to other studies, the magnitude of the root mean square error (RMSE) from our study (i.e., 0.69) was just about the average RMSE obtained from other studies that deal with medium-sized rivers (200$800 \mathrm{~m}$ in width) (Table 3).

It is important to note that we did not adjust the magnitude of the satellite altimetry range measurements in any way. Apart from the spatial selection of the range measurements with the projected nadir footprint center within the water body and the removal of outliers, the only manipulation we performed was selecting the range measurements based on its waveform shape to strictly follow the standard waveform shape for an inland water body as described in the previous studies (Koblinsky et al., 1993; Birkett, 1988; Berry et al., 2005; Dabo-Niang et al., 2007). Therefore, there are several possibilities for improvement to increase the accuracy of the satellite altimetry measurement of river water levels, especially for this study area. Examples are the use of other altimetry missions (e.g., Jason-1, ICESat), more detailed evaluation of retracked water elevation within a cycle, and inclusion of the actual river slope in the processing.

In this study, we found that Envisat altimetry showed a potential to observe small-sized rivers. Satellite altimetry crossing at the UM03 virtual station returned a high percentage of qualified measurement even with fewer measurements within the water body (i.e., 46 over 51) compared to that of other virtual stations. Figure 8 indicates the water level fluctuation at this virtual station, while Fig. 9 shows variable gaps that existed between the measurements, with an average of 84 days and a maximum gap that lasted for 300 days ( $\sim 10$ months). This temporal gap was a serious problem for hydrological applications, especially those requiring the measurement of hydrological variables at short intervals. Furthermore, there 


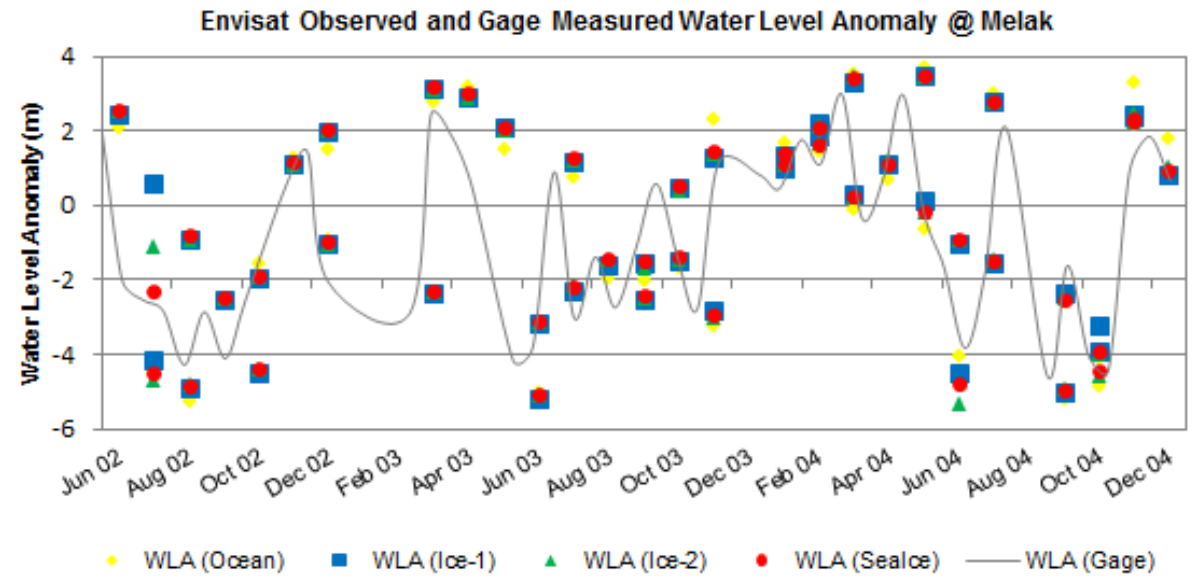

Figure 6. Water level anomaly at Melak as observed by two Envisat passes and retracked by four retrackers, compared with the in situ water level anomaly.
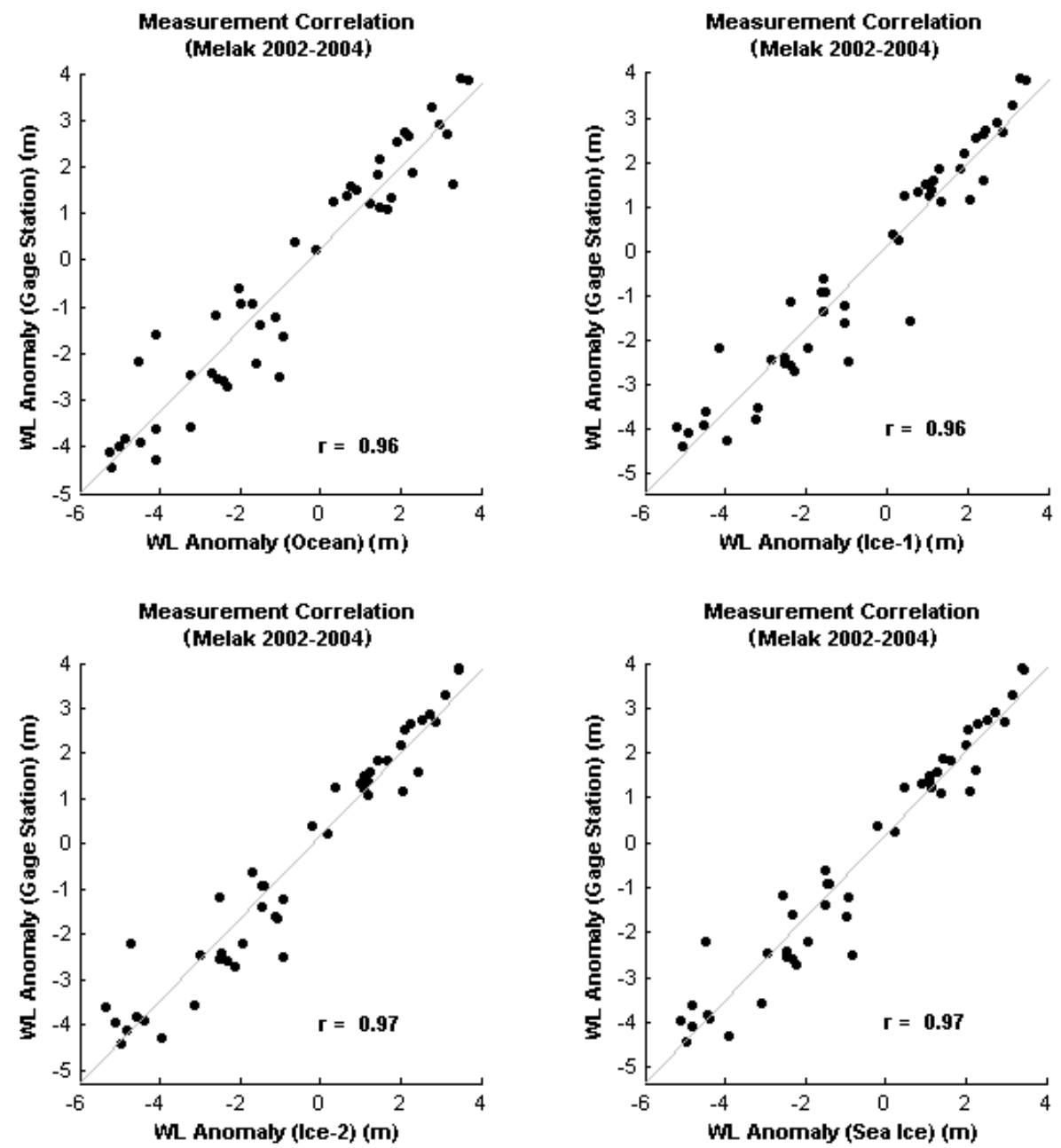

Figure 7. Correlation between the water level anomaly measured by the Envisat altimeter and processed with the Ocean (top left panel), Ice-1 (top right panel), Ice-2 (bottom left panel) and Sea Ice (bottom right panel) retrackers and the in situ water level measurement over Melak. 
Table 3. Summary of studies on satellite radar altimetry for water level over river.

\begin{tabular}{|c|c|c|c|c|}
\hline Reference & Location & $\begin{array}{l}\text { River } \\
\text { width }\end{array}$ & $\begin{array}{l}\text { Satellite/ } \\
\text { sensor }\end{array}$ & Reported error (m) \\
\hline Koblinsky et al. (1993) & Amazon Basin & N/A & Geosat & STDE* : 0.31-1.68 m \\
\hline Birkett (1998) & Amazon Basin & $3-9 \mathrm{~km}$ & $\mathrm{~T} / \mathrm{P}$ & RMSE$^{*}: 0.11-0.60 \mathrm{~m}$ \\
\hline Birkett et al. (2002) & Amazon Basin & $2-6 \mathrm{~km}$ & $\mathrm{~T} / \mathrm{P}$ & RMSE $^{*}: 0.40-0.60 \mathrm{~m}$ \\
\hline Kouraev et al. (2004) & Ob' River & $3 \mathrm{~km}$ & $\mathrm{~T} / \mathrm{P}$ & $\%^{*}: 8 \%($ discharge $)$ \\
\hline Frappart et al. (2006) & Mekong River & $450 \mathrm{~m}$ & $\begin{array}{l}\text { Envisat, } \\
\mathrm{T} / \mathrm{P}\end{array}$ & $\begin{array}{l}\text { RMSE}^{*}: 0.23 \mathrm{~m} \\
\text { RMSE}^{*}: 0.15 \mathrm{~m}\end{array}$ \\
\hline Birkinshaw et al. (2010) & Mekong River & $\begin{array}{l}400 \mathrm{~m}- \\
1.7 \mathrm{~km}\end{array}$ & $\begin{array}{l}\text { ERS-2, } \\
\text { Envisat }\end{array}$ & RMSE*: 0.44-1.24 m \\
\hline Kuo and Kao (2011) & Bajhang River & $100 \mathrm{~m}$ & Jason-2 & STDE $^{*}: 0.31 \mathrm{~m}$ \\
\hline Michailovsky et al. (2012) & Zambezi River & $40-380 \mathrm{~m}$ & Envisat & RMSE* $^{*}$ 0.27-1.07 m \\
\hline This study (2013) & Mahakam River & $240-279 \mathrm{~m}$ & Envisat & RMSE$^{*}: 0.69 \mathrm{~m}$ \\
\hline
\end{tabular}

$* \mathrm{STDE}=$ standard deviation of error, $\%=\%$ difference, $\mathrm{RMSE}=$ root mean square error.

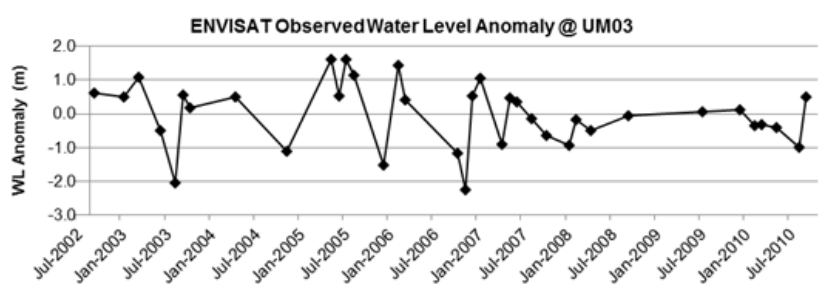

Figure 8. ENVISAT observed water level anomaly at site UM03 (river width $54 \mathrm{~m}$ ) as measured by Envisat RA-2 and processed by the Ice-1 retracker.

was no in situ gauge station in the vicinity that provided validation data for this particular virtual station (UM03). Although we could not validate the water level retrievals at this location, this experiment showed the potential of satellite altimetry for monitoring small rivers (40-200 $\mathrm{m}$ in width).

We conducted another experiment of satellite altimetry measurement over the narrow Karangmumus River (width 8-45 m). The northeast-southwest orientation of this river made it difficult to find the crossing with Envisat ground tracks. However, a high-resolution IKONOS image $(1 \mathrm{~m}$ ground resolution) allowed detailed selection of the altimeter ground tracks that fall within its narrow channel. Still, the ultra-narrow channel width seriously hampered successful satellite radar altimetry measurement of this study site. After careful spatial filtering and a waveform shape selection procedure, we extracted only 11 water surface elevations from the Karangmumus River. Figure 10 depicts the location of this experiment, while Table 4 summarizes the qualified measurements.

Figure 11 shows the time series of the Karangmumus River water level anomaly from 2004 to 2006, and it is obvious that the number of retrieved water level anomalies was very limited. In addition, the in situ measurement record from the nearest available gauge stations (i.e., Pampang, Muang, Gununglingai and the outlet of the Karangmumus

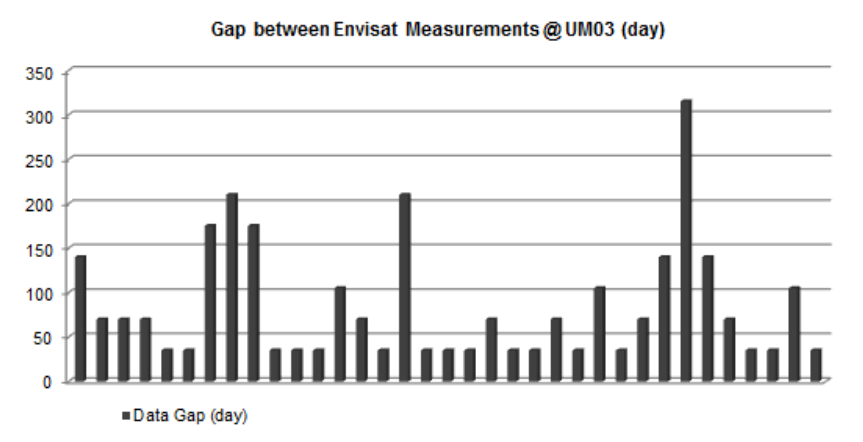

Figure 9. Gaps between Envisat observations of water levels over site UM03.

River) were available only during years 2008-2010. Therefore, we could not evaluate the performance of satellite altimetry measurements over this very small river. However, this result serves as a preliminary indication of the range of water level magnitude in this river.

Presently, only a few other studies indicated successful exploitation of the rivers with $100 \mathrm{~m}$ in width or less. Michailovsky et al. (2012) extracted 13 useful water level measurements from a river with $40 \mathrm{~m}$ in width and Kuo and Kao (2011) revealed the water level of the Bajhang River in Taiwan with less than $100 \mathrm{~m}$ in width with a standard deviation of error of $0.31 \mathrm{~m}$.

We therefore urge further exploration of satellite altimetry observations to monitor small rivers supported by complete validation data.

To conclude this section, we demonstrated that mediumsized rivers as narrow as $240 \mathrm{~m}$ can still be monitored and validated, provided that the water surface boundary was identified accurately. This result expands the capability of the satellite altimetry, since previous studies showed that $1 \mathrm{~km}$ seems to be the ideal width from which to expect typical altimetry radar returns from the water surface (Birkett, 
Table 4. Qualified Envisat RA-2 altimetry measurements for the Karangmumus River.

\begin{tabular}{lllllrl}
\hline Cycle & Date & ID & Longitude & Latitude & $\begin{array}{r}\text { Water } \\
\text { level }\end{array}$ & Remarks \\
& & & & & & \\
anomaly* & \\
\hline 8 & 23 Jul 2002 & KM08 & 117.181540 & -0.404124 & $-0.07 \mathrm{~m}$ & \\
9 & 27 Aug 2002 & KM10 & 117.194581 & -0.408362 & $-4.52 \mathrm{~m}$ & Benanga Reservoir \\
13 & 13 Jan 2003 & KM11 & 117.195384 & -0.407573 & $2.94 \mathrm{~m}$ & Benanga Reservoir \\
23 & 30 Dec 2003 & KM01 & 117.157190 & -0.507934 & $-1.92 \mathrm{~m}$ & \\
23 & 30 Dec 2003 & KM02 & 117.157910 & -0.504634 & $-2.32 \mathrm{~m}$ & \\
28 & 22 Jun 2004 & KM09 & 117.188367 & -0.405981 & $3.63 \mathrm{~m}$ & $47 \mathrm{~m}$ to field gauge \\
37 & 3 May 2005 & KM06 & 117.169721 & -0.448573 & $-0.11 \mathrm{~m}$ & \\
37 & 3 May 2005 & KM07 & 117.170441 & -0.445263 & $-0.12 \mathrm{~m}$ & \\
39 & 12 Jul 2005 & KM03 & 117.158610 & -0.503317 & $-2.28 \mathrm{~m}$ & \\
42 & 25 Oct 2005 & KM05 & 117.171486 & -0.452076 & $4.12 \mathrm{~m}$ & \\
49 & 27 Jun 2006 & KM04 & 117.159139 & -0.501533 & $-0.93 \mathrm{~m}$ & \\
\hline
\end{tabular}

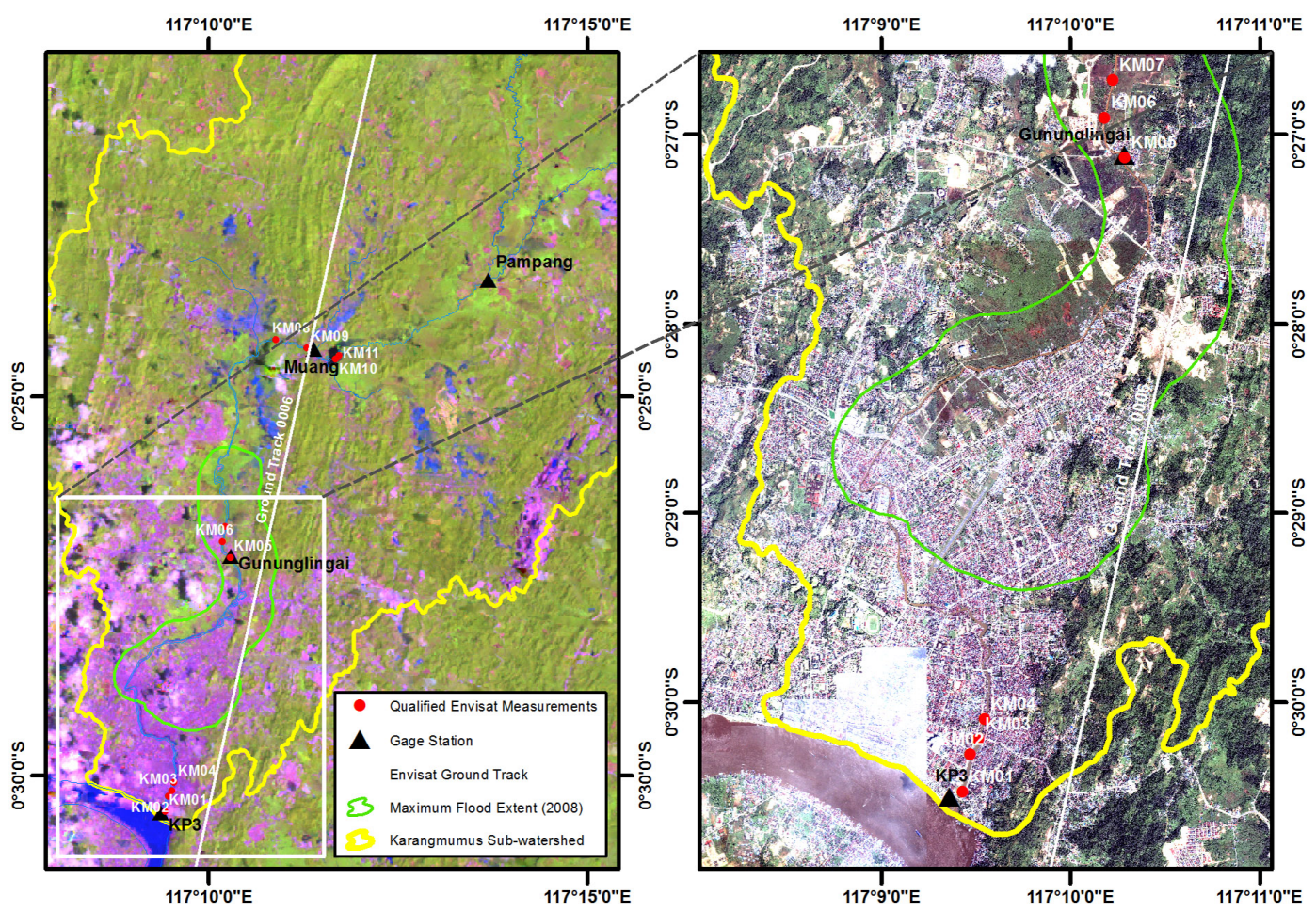

Figure 10. The Karangmumus sub-watershed. Left panel: overview of the sub-watershed with Landsat-7 image of January 2007 as the background. Right panel: detailed view of the urbanized downstream part with IKONOS image of February 2002 as the background. Envisat ground tracks appear as white lines in both panels.

1998; Birkett et al., 2002). We also emphasize that successful retrieval of qualified satellite radar altimetry measurement in this research was very much supported by detailed geographic masking, which carefully excluded all altimetry measurements with a projected nadir position outside of the water bodies.

\subsection{Lake Matano and Lake Towuti}

Inland water has been known to produce different, sometimes irregular, waveform shapes and patterns as compared to that of the ocean. In particular is the difference with respect to their responses to radar pulse signals transmitted by satellitebased active sensors. Some examples of distinguished waveform shapes from Lake Matano and Lake Towuti at different buffer distances from the lakeshore are presented in Fig. 12. 
Table 5. The number of qualified and non-qualified altimeter measurements and outliers over Lake Matano and Lake Towuti.

\begin{tabular}{|c|c|c|c|c|c|c|c|c|c|}
\hline \multirow[t]{3}{*}{ Location } & \multirow[t]{3}{*}{ Width } & \multirow[t]{3}{*}{ Cycle } & \multirow{3}{*}{$\begin{array}{l}\text { Distance to } \\
\text { shore }\end{array}$} & \multirow{3}{*}{$\begin{array}{r}\text { Measurement } \\
\text { within water } \\
\text { body }\end{array}$} & \multicolumn{2}{|c|}{ Qualified } & \multirow{2}{*}{\multicolumn{2}{|c|}{$\begin{array}{c}\text { Non- } \\
\text { qualified }\end{array}$}} & \multirow{3}{*}{$\begin{array}{l}\text { No. of } \\
\text { outliers }\end{array}$} \\
\hline & & & & & \multirow[t]{2}{*}{ No. } & \multirow[t]{2}{*}{$\%$} & & & \\
\hline & & & & & & & No. & $\%$ & \\
\hline Lake & 8159 & $8-79$ & $<500 \mathrm{~m}$ & 453 & 416 & 91.8 & 37 & 8.2 & 42 \\
\hline \multirow[t]{2}{*}{ Matano } & & & $500 \mathrm{~m}-1 \mathrm{~km}$ & 253 & 215 & 85.0 & 38 & 15.0 & 26 \\
\hline & & & $>1 \mathrm{~km}$ & 989 & 805 & 81.4 & 184 & 18.6 & 115 \\
\hline Lake & 28818 & $8-79$ & $<500 \mathrm{~m}$ & 1314 & 786 & 59.8 & 528 & 40.2 & 79 \\
\hline \multirow[t]{2}{*}{ Towuti } & & & $500 \mathrm{~m}-1 \mathrm{~km}$ & 1328 & 764 & 57.5 & 564 & 42.5 & 64 \\
\hline & & & $>1 \mathrm{~km}$ & 2450 & 1353 & 54.3 & 1137 & 45.7 & 156 \\
\hline
\end{tabular}

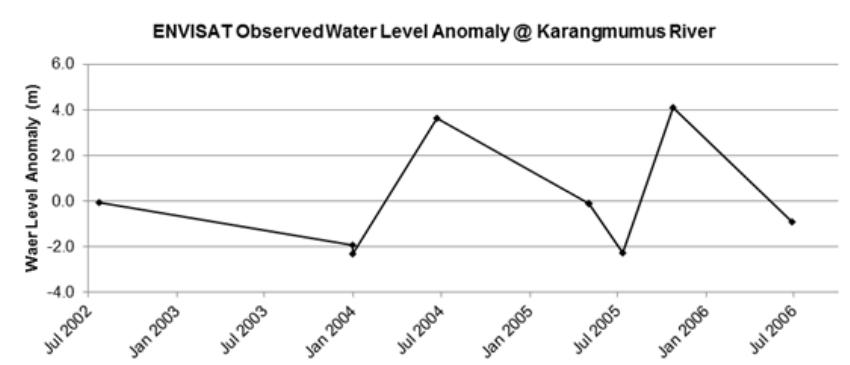

Figure 11. Water level anomaly of the Karangmumus River from Envisat RA-2, processed by Ice-1 retracker.

Our findings indicated that the waveform shapes resulting from satellite altimetry measurement over the lakes had more variability compared to those over the small to medium-sized rivers. We suspect this was due to the fact that lakes possess a larger extent of water surface and are much more influenced by wind that may develop waves with some height. Figure 12 shows the typical ocean-like, multi- and low-peak, gradually rising and many other kinds of irregular patterns that were not present in the data set from small and mediumsized rivers. Up to now, a systematic and verified classification of waveform shapes, especially for inland waters, has not existed, except for the early development such as presented by Dabo-Niang et al. (2007): hence the need to study this subject further.

Table 5 summarizes the results of satellite altimetry waveform selection over Lake Matano and Lake Towuti. Similar to the result of satellite altimetry measurements for small to medium-sized rivers in the previous section, most of the radar pulse returns produced qualified waveforms that were subsequently used to compute the water level anomalies at these two lakes. Our findings suggested that the separation distance from the lakeshore did not significantly affect the number of qualified waveforms. For instance, the percentage of qualified waveforms for the lake surface with a distance from the lakeshore of more than $1 \mathrm{~km}$ in Lake Matano and Lake Towuti was lower than those closer to the lakeshore (Table 5). This complex result calls for further investigation in the field of satellite altimetry application for small and medium lakes in the tropics, given the fact that the land cover does not always influence the shapes of the returned altimeter waveform.

Upon the completion of waveform sorting, we processed the range measurements performed by the Ocean, Ice-1, Ice2 and Sea Ice retrackers and evaluated them against observed water levels from the in situ gauge station. Figures 13 and 14 show the satellite altimetry and in situ measured water level anomaly at Lake Matano and Lake Towuti. These plots visually indicate that the satellite altimetry-observed water level anomalies closely matched the in situ gauged water level anomaly. From Figs. 13 and 14, we estimated the range of the water level anomaly at Lake Matano to be in the magnitude of $1.2 \mathrm{~m}$, while that of Lake Towuti only ranged in the magnitude of $1.4 \mathrm{~m}$. Figures 15 and 16 show the correlation between the Envisat radar altimeter measurements as processed by the Ocean, Ice-1, Ice- 2 and Sea Ice retrackers with the gauge-measured water level anomaly for Lake Matano and Lake Towuti, respectively.

In terms of performance, Envisat radar altimetry measurements over Lake Matano and Lake Towuti performed equally well, as reflected by the lowest RMSE obtained by the best retracker for each lake (0.21, see Table 6). Based on the performance evaluation (Table 6), our results could not verify the hypothesis that the shorter distance to the lakeshore was associated with a lower accuracy of satellite altimetry measurement. The satellite altimetry measurements of the water level anomaly over Lake Matano indicated better accuracy (lower RMSE and higher correlation coefficient) as the distance between the altimeter footprint and the lakeshore increased, whereas measurements over Lake Towuti showed the opposite (see Figs. 17 and 18). These inconclusive results further suggest the use of a sample classification based on the distance to the lakeshore for future investigation.

Intercomparison between the available retrackers (i.e., Ocean, Ice-1, Ice-2 and Sea Ice) also cannot convincingly suggest any single retracker to infer the water level of the small lakes, since the Ocean retracker surprisingly performed best for Lake Matano, while the Ice-1 retracker 

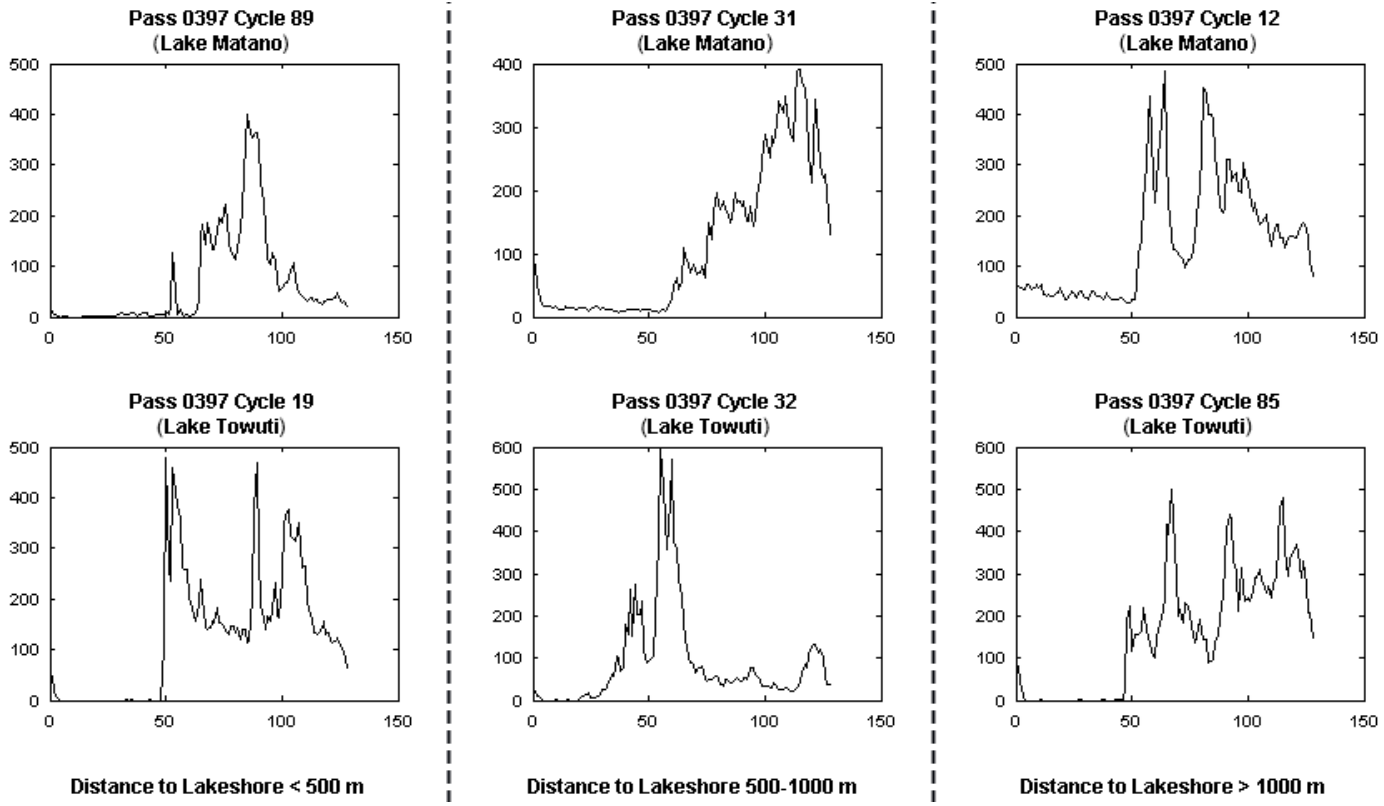

Figure 12. Distinguished waveform shapes as reflected by Lake Matano and Lake Towuti at different buffer distances to the lakeshore.

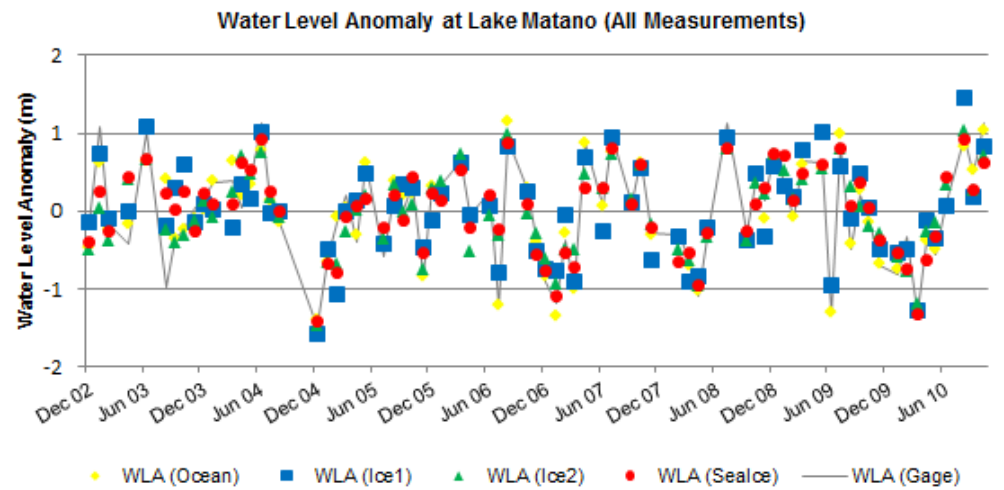

Figure 13. Water level anomaly at Lake Matano as measured by Envisat RA-2 and processed by all retrackers, compared with in situ measurement.

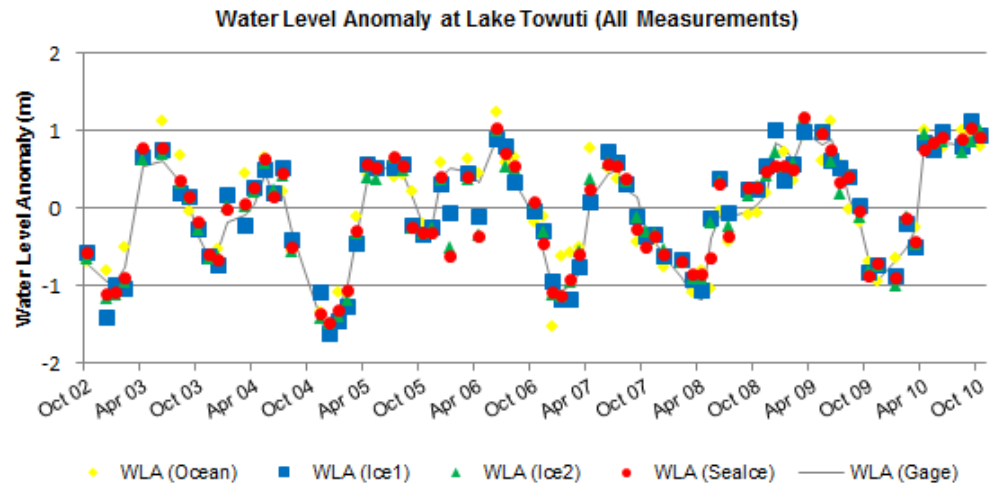

Figure 14. Water level anomaly at Lake Towuti as measured by Envisat RA-2 and processed by all retrackers, compared with in situ measurement. 

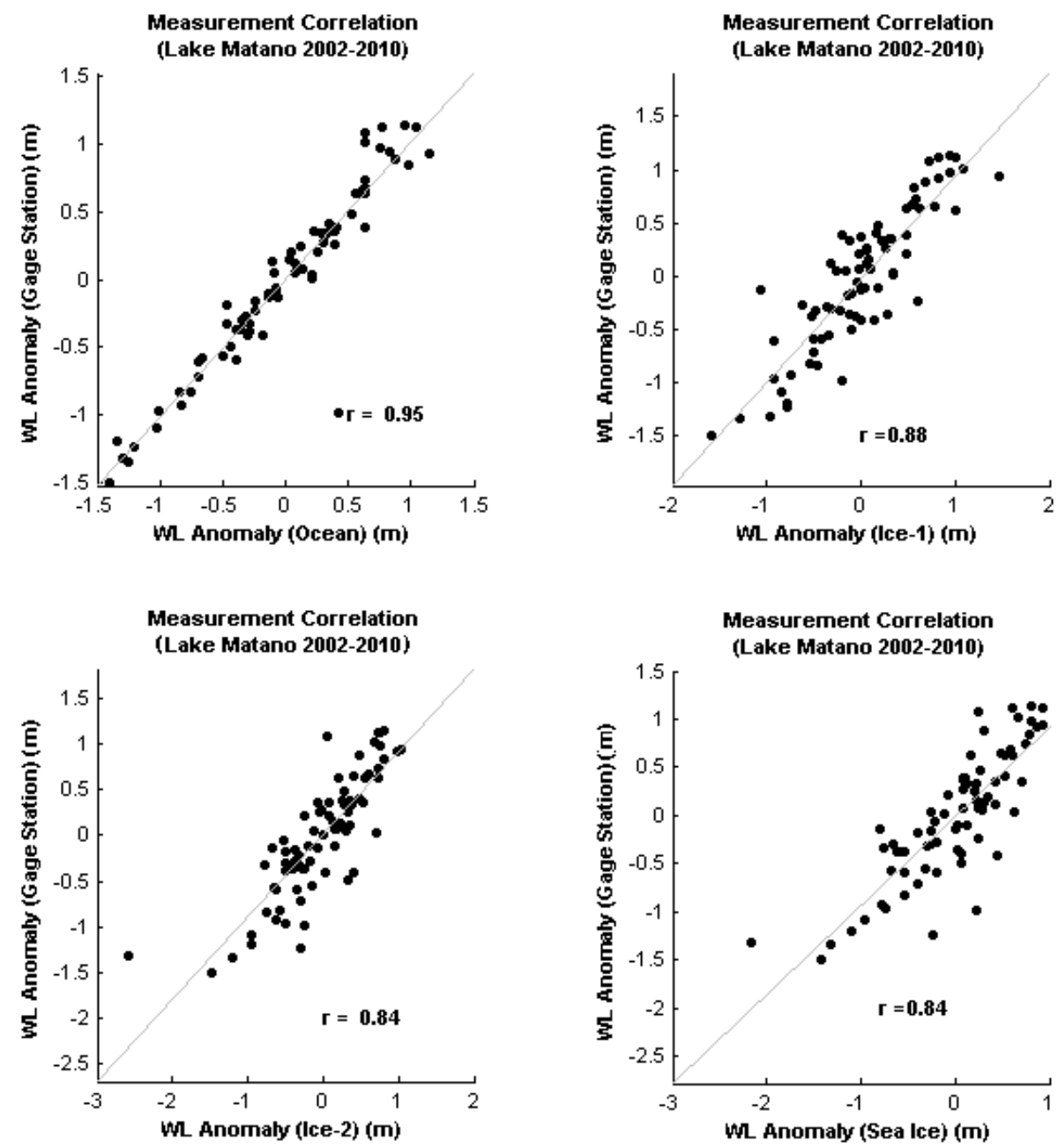

Figure 15. Correlation between the water level anomaly at Lake Matano as measured by the Envisat RA-2 altimeter and processed with the Ocean (top left panel), Ice-1 (top right panel), Ice-2 (bottom left panel) and Sea Ice (bottom right panel) retrackers.

performed best for Lake Towuti. An important conclusion from this study is that Ice-1 is not necessarily the best retracker for measuring water level anomaly over small to medium lakes.

The best RMSE obtained from measurements of water level anomaly in this study $(0.21 \mathrm{~m}$ at both Lake Matano and Lake Towuti) was quite close to the lowest RMSE in other similar studies (e.g., Coe and Birkett, 2004; Munyaneza et al., 2009; Cai and Ji, 2009). Table 7 states that satellite altimetry measurements over small lakes produced RMSE magnitudes in the range of 30 to $50 \mathrm{~cm}$, as compared to large lakes that produced an RMSE as low as $3 \mathrm{~cm}$. Lake Matano is in fact the smallest among all the lakes listed in Table 7.

\section{Conclusions}

In this study we demonstrated the ability of satellite altimetry to monitor the water level of medium-sized $(200-800 \mathrm{~m}$ in width) rivers in Southeast Asia's humid tropics with high accuracy (correlation coefficient of 0.97 and an RMSE of $0.685 \mathrm{~m}$ ). Despite its performance variability, the water level anomaly inferred by Envisat radar altimetry through the standard waveform retracking method was validated in this study. These results thus confirmed its ability to monitor water level fluctuations in medium-sized rivers. In addition to the medium-sized rivers, we found that small rivers $(40-200 \mathrm{~m}$ in width) are potentially observable through satellite altimetry, as indicated by the high percentage of qualified range measurements that we filtered based on the waveform shapes. It is important to note however that there could possibly be a variation in the measurement capability and accuracy across different regions; therefore, a specific approach should be developed for each region, as part of the development of a permanent monitoring effort in those regions.

In contrast to what was previously found (Frappart et al., 2006), Ice-1 is not necessarily the best retracker for monitoring small water bodies, especially for the Southeast Asia hu- 

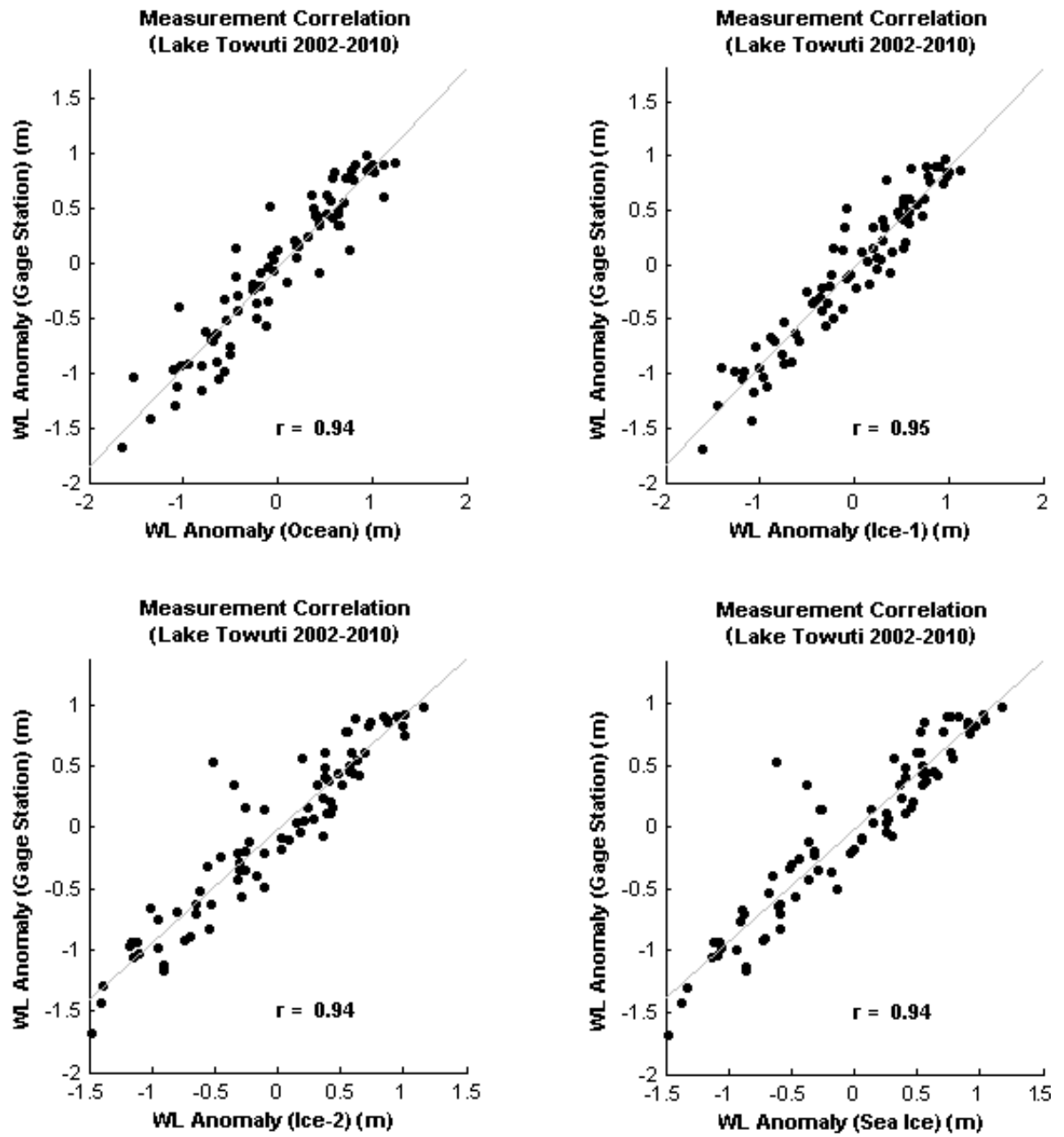

Figure 16. Correlation between the water level anomaly at Lake Towuti as measured by the Envisat RA-2 altimeter and processed with the Ocean (top left panel), Ice-1 (top right panel), Ice-2 (bottom left panel) and Sea Ice (bottom right panel) retrackers.
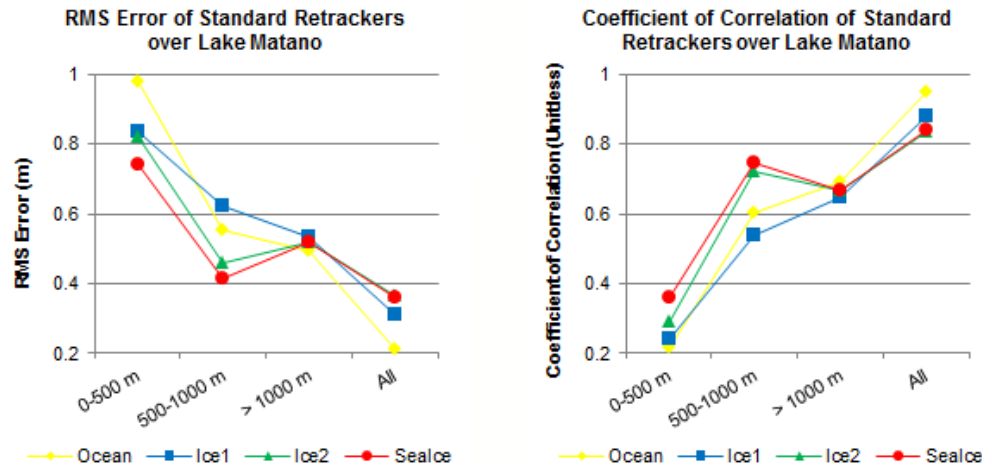

Figure 17. The performance of Envisat RA-2 radar altimetry measurements over Lake Matano, classified by the distance to the lakeshore. 

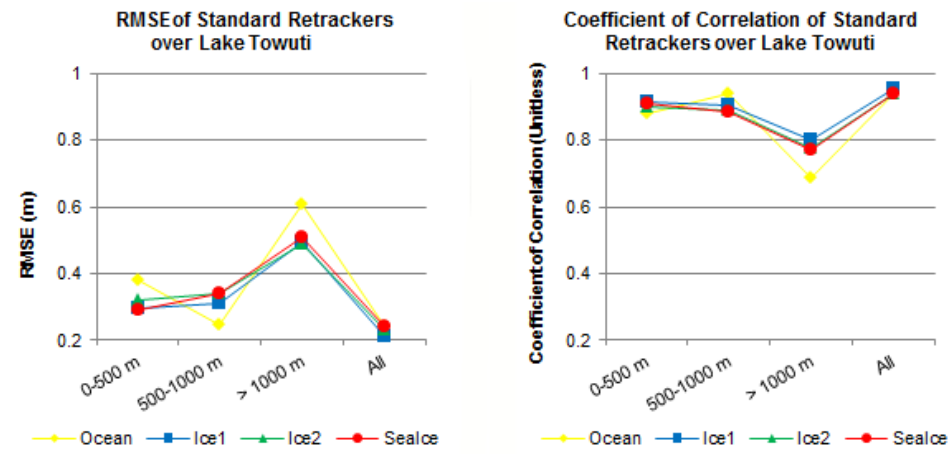

Figure 18. The performance of Envisat RA-2 radar altimetry measurements over Lake Towuti, classified by the distance to the lakeshore.

Table 6. Performance evaluation of Envisat RA-2 radar altimetry measurements over Lake Matano and Lake Towuti.

\begin{tabular}{|c|c|c|c|c|c|c|c|}
\hline Site & $\begin{array}{r}\text { Lake } \\
\text { width } \\
(\mathrm{m})\end{array}$ & Cycles & $\begin{array}{c}\text { Validated } \\
\text { measurement }\end{array}$ & Re-tracker & $\begin{array}{l}\text { Correlation } \\
\text { coefficient }\end{array}$ & $\begin{array}{l}\text { RMSE } \\
(\mathrm{m})\end{array}$ & $\begin{array}{l}\text { No. } / \% \text { of } \\
\text { outliers }\end{array}$ \\
\hline Lake Matano & 8159 & $8-79$ & & & & & \\
\hline \multirow[t]{4}{*}{$0-500 \mathrm{~m}$} & & & 75 & Ocean & 0.214 & 0.981 & $42 / 387$ \\
\hline & & & & Ice-1 & 0.242 & 0.835 & $10.85 \%$ \\
\hline & & & & Ice-2 & 0.290 & 0.819 & \\
\hline & & & & Sea Ice & 0.358 & 0.743 & \\
\hline \multirow[t]{4}{*}{$500-1000 \mathrm{~m}$} & & & 71 & Ocean & 0.605 & 0.555 & $26 / 214$ \\
\hline & & & & Ice-1 & 0.538 & 0.624 & $12.15 \%$ \\
\hline & & & & Ice-2 & 0.723 & 0.458 & \\
\hline & & & & Sea Ice & 0.745 & 0.417 & \\
\hline \multirow[t]{4}{*}{$>1000 \mathrm{~m}$} & & & 73 & Ocean & 0.692 & 0.493 & $115 / 805$ \\
\hline & & & & Ice-1 & 0.647 & 0.535 & $14.29 \%$ \\
\hline & & & & Ice-2 & 0.667 & 0.518 & \\
\hline & & & & Sea Ice & 0.666 & 0.518 & \\
\hline \multirow[t]{4}{*}{ All } & & & 75 & Ocean & 0.948 & 0.209 & $183 / 1406$ \\
\hline & & & & Ice-1 & 0.881 & 0.311 & $13.02 \%$ \\
\hline & & & & Ice-2 & 0.837 & 0.364 & \\
\hline & & & & Sea Ice & 0.839 & 0.359 & \\
\hline Lake Towuti & 28818 & $8-79$ & & & & & \\
\hline \multirow[t]{4}{*}{$0-500 \mathrm{~m}$} & & & 77 & Ocean & 0.880 & 0.380 & $79 / 786$ \\
\hline & & & & Ice-1 & 0.917 & 0.296 & $10.05 \%$ \\
\hline & & & & Ice-2 & 0.898 & 0.321 & \\
\hline & & & & Sea Ice & 0.911 & 0.291 & \\
\hline \multirow[t]{4}{*}{$500-1000 \mathrm{~m}$} & & & 79 & Ocean & 0.942 & 0.244 & $64 / 764$ \\
\hline & & & & Ice-1 & 0.903 & 0.312 & $8.38 \%$ \\
\hline & & & & Ice-2 & 0.890 & 0.339 & \\
\hline & & & & Sea Ice & 0.887 & 0.341 & \\
\hline \multirow[t]{4}{*}{$>1000 \mathrm{~m}$} & & & 79 & Ocean & 0.689 & 0.608 & $156 / 1353$ \\
\hline & & & & Ice-1 & 0.802 & 0.494 & $11.53 \%$ \\
\hline & & & & Ice-2 & 0.777 & 0.490 & \\
\hline & & & & Sea Ice & 0.774 & 0.507 & \\
\hline \multirow[t]{4}{*}{ All } & & & 80 & Ocean & 0.940 & 0.241 & $299 / 2903$ \\
\hline & & & & Ice-1 & 0.953 & 0.212 & $10.30 \%$ \\
\hline & & & & Ice-2 & 0.941 & 0.231 & \\
\hline & & & & Sea Ice & 0.938 & 0.239 & \\
\hline
\end{tabular}


Table 7. Summary of studies on satellite radar altimetry for water levels over lakes.

\begin{tabular}{|c|c|c|c|c|}
\hline Reference & Location & Lake extent & $\begin{array}{l}\text { Satellite/ } \\
\text { sensor }\end{array}$ & Reported error \\
\hline Morris and Gill (1994a) & $\begin{array}{l}\text { Superior, Ontario } \\
\text { Michigan, Huron } \\
\text { Erie } \\
\text { Lake St. Clair }\end{array}$ & $\begin{array}{l}\text { Large } \\
\text { Large }\end{array}$ & $\begin{array}{l}\text { Geosat } \\
\text { Geosat } \\
\text { Geosat } \\
\text { Geosat }\end{array}$ & $\begin{array}{l}\mathrm{RMSE}^{*}: 0.09 \mathrm{~m} \\
\mathrm{RMSE}^{*}: 0.11 \mathrm{~m} \\
\mathrm{RMSE}^{*}: 0.13 \mathrm{~m} \\
\mathrm{RMSE}^{*}: 0.17 \mathrm{~m}\end{array}$ \\
\hline Morris and Gill (1994b) & Great Lakes & & $\begin{array}{l}\text { Topex/ } \\
\text { Poseidon }\end{array}$ & $\mathrm{RMSE}^{*}: 0.03 \mathrm{~m}$ \\
\hline Korotaev et al. (2001) & Black Sea & $436402 \mathrm{~km}^{2}$ & T/P, ERS-1 & $\mathrm{RMSE}^{*}: 0.03 \mathrm{~m}$ \\
\hline \multirow[t]{2}{*}{ Mercier et al. (2002) } & $\begin{array}{l}\text { Victoria, } \\
\text { Tanganyika } \\
\text { Malawi and } \\
\text { Turkana }\end{array}$ & $131-390 \times 10^{3}$ & $\begin{array}{l}\text { TOPEX/ } \\
\text { Poseidon }\end{array}$ & RMSE* $^{*} 0.10 \mathrm{~m}$ \\
\hline & $\begin{array}{l}\text { Rukwa and } \\
\text { Kyoga }\end{array}$ & $75-80 \times 10^{3}$ & $\begin{array}{l}\text { TOPEX/ } \\
\text { Poseidon }\end{array}$ & $\mathrm{RMSE}^{*}: 0.50 \mathrm{~m}$ \\
\hline Coe and Birkett (2004) & Lake Chad & $2.5 \times 10^{6} \mathrm{~km}^{2}$ & $\begin{array}{l}\text { TOPEX/ } \\
\text { Poseidon }\end{array}$ & $\mathrm{RMSE}^{*}: 0.21 \mathrm{~m}$ \\
\hline Zhang et al. (2006) & Dongting Lake & $2623 \mathrm{~km}^{2}$ & $\begin{array}{l}\text { TOPEX/ } \\
\text { Poseidon }\end{array}$ & $\mathrm{RMSE}^{*}: 0.08 \mathrm{~m}$ \\
\hline Medina et al. (2008) & Lake Izabal & $717 \mathrm{~km}^{2}$ & Envisat & $\mathrm{RMSE}^{*}: 0.09 \mathrm{~m}$ \\
\hline Munyaneza et al. (2009) & Lake Kivu & $2400 \mathrm{~km}^{2}$ & Envisat & RMSE*: $0.30 \mathrm{~m}$ \\
\hline Cai and Ji (2009) & Poyang Lake & $20290 \mathrm{~km}^{2}$ & Envisat & Mean Error: $0.31 \mathrm{~m}$ \\
\hline Guo et al. (2009) & Hulun Lake & $2339 \mathrm{~km}^{2}$ & $\begin{array}{l}\text { TOPEX/ } \\
\text { Poseidon }\end{array}$ & $\mathrm{RMSE}^{*}: 0.13 \mathrm{~m}$ \\
\hline Troitskaya et al. (2012) & $\begin{array}{l}\text { Gorki } \\
\text { Reservoir }\end{array}$ & $1358 \mathrm{~km}^{2}$ & T/P, Jason-1 & RMSE* $^{*}: 0.15 \mathrm{~m}$ \\
\hline Tseng et al. (2013) & Qinghai Lake & $4186 \mathrm{~km}^{2}$ & Envisat & RMSE* $0.06 \mathrm{~m}$ \\
\hline This study & $\begin{array}{l}\text { Lake Matano } \\
\text { Lake Towuti }\end{array}$ & $\begin{array}{l}164 \mathrm{~km}^{2} \\
562 \mathrm{~km}^{2}\end{array}$ & $\begin{array}{l}\text { Envisat } \\
\text { Envisat }\end{array}$ & $\begin{array}{l}\mathrm{RMSE}^{*}: 0.21 \mathrm{~m} \\
\mathrm{RMSE}^{*}: 0.21 \mathrm{~m}\end{array}$ \\
\hline
\end{tabular}

$*$ RMSE $=$ root mean square error.

mid tropics area. We also found that the Ocean retracker surprisingly performed best for retracking small lakes (i.e., Lake Matano), as well as Sea Ice for the Mahakam River and Ice-1 for Lake Towuti.

The RMSE of satellite altimetry measurement of Lake Matano and Lake Towuti ( $0.21 \mathrm{~m}$ for both locations) falls within the range of RMSE of small lakes observed by satellite altimetry throughout the world (e.g., between 0.03 and $0.50 \mathrm{~m})$. It is worth noting that Lake Matano is the smallest water body analyzed from satellite altimetry.

Considering the results of this study, we recommend the following: (1) in addition to the use of standard retrackers, we propose the selection of altimetry measurements based on the waveform shape to filter out returned radar signals contaminated by non-water surfaces. We recommend the selection to strictly follow the standard waveform shape for inland water bodies (Koblinsky et al., 1993; Birkett, 1998; Berry et al., 2005; Dabo-Niang et al., 2007), especially for studies involving small (40-200 $\mathrm{m}$ in width) to medium rivers $(200-800 \mathrm{~m}$ in width), as well as small lakes (e.g., those with an extent of less than $1000 \mathrm{~km}^{2}$ ), and, (2) over lakes, we do not recommend analyzing the performance of the satellite altimetry retrackers based on the distance from the satellite altimetry measurements to the lakeshore.

Lastly, we found that the geographic orientation of the river affected the application of satellite altimetry for monitoring small rivers. For instance, small (40-200 $\mathrm{m}$ in width) and medium-sized (200-800 $\mathrm{m}$ in width) rivers with a northsouth orientation suffered from the satellite altimetry orbit 
deviation, which ranges from $\pm 1 \mathrm{~km}$ relative to its theoretical orbit.

\section{The Supplement related to this article is available online at doi:10.5194/hess-12-341-2015-supplement.}

Acknowledgements. This research was primarily supported by the Fulbright $\mathrm{PhD}$ Presidential Scholarship administered by the American Indonesian Exchange Foundation (AMINEF) and the Institute for International Education (IIE). In addition, this study was partially funded by grants from NASA's Application Science Program under the SERVIR project (NNX12AM85G), and by the Chinese Academy of Sciences/SAFEA International Partnership Program for Creative Research Teams (grant no. KZZD-EW-TZ05). The authors greatly appreciate the Ministry of Public Works of Republic of Indonesia and PT Vale Indonesia, Tbk for providing the in situ water level data used in this research. The first author is supported by an appointment to the NASA Postdoctoral Program at the NASA Goddard Space Flight Center, administered by Oak Ridge Associated Universities through a contract with NASA. We thank the editor, Paola Passalacqua, anonymous referees and Radina Soebiyanto for their help in improving this manuscript.

Edited by: P. Passalacqua

\section{References}

Alsdorf, D. E. and Lettenmaier, D. P.: Tracking fresh water from space, Science, 301, 1491-1494, 2003.

Bamber, J. L.: Ice sheet altimeter processing scheme, Int. J. Remote Sens., 15, 925-938, 1994.

Bao, L., Lu, Y., and Wang, Y.: Improved retracking algorithm for oceanic altimeter waveforms, Prog. Nat. Sci., 19, 195-203, 2009.

Benveniste, J. and Defrenne, D.: Radar Altimetry Processing for Inland Waters: Introduction and Background Review, Slides presented at Workshop on Hydrology from Space, 29 September1 October 2003, Touluse, 2003.

Berry, P. A. M., Garlick, J. D., Freeman, J. A., and Mathers, E. L.: Global inland water monitoring from multi-mission altimetry, Geophys. Res. Lett., 32, L16401, doi:10.1029/2005GL022814, 2005.

Birkett, C. M.: Contribution of the TOPEX NASA radar altimeter to the global monitoring of large rivers and wetlands, Water Resour. Res., 34, 1223-1239, 1998.

Birkett, C. M., Mertes, L. A. K., Dunne, T., Costa, M. H., and Jasinski, M. J.: Surface water dynamics in the Amazon Basin: application of satellite radar altimetry, J. Geophys. Res., 107, 8059, doi:10.1029/2001JD000609, 2002.

Birkinshaw, S. J., O’Donnell, G. M., Moore, P., Kilsby, C. G., Fowler, H. J., and Berry, P. A. M.: Using satellite altimetry data to augment flow estimation techniques on the Mekong River, Hydrol. Process., 24, 3811-3825, doi:10.1002/hyp.7811, 2010.

Brown, G. S.: The average impulse response of a rough surface and its applications, IEEE T. Antennas Propag., 25, 67-74, doi:10.1109/TAP.1977.1141536, 1977.
Brown, O. B. and Cheney, R. E.: Advances in satellite oceanography, Rev. Geophys., 21, 1216-1230, 1983.

Cai, X. and Ji, W.: Wetland hydrologic application of satellite altimetry - A ase study in the Poyang Lake watershed, Prog. Nat. Sci., 19, 1781-1787, doi:10.1016/j.pnsc.2009.07.004, 2009.

Calmant, S. and Seyler, F.: Continental surface waters from satellite altimetry, internal geophysics (space physics), C. R. Geoscience, 338, 1113-1122, 2006.

Coe, M. T. and Birkett, C. M.: Calculation of river discharge and prediction of lake height from satellite radar altimetry: Example for the Lake Chad basin, Water Resour. Res., 40, W10205, doi:10.1029/2003WR002543, 2004.

Cretaux, J.-F., Jelinski, W., Calmant, S., Kouraev, A., Vuglinski, V., Berge-Nguyen, M., Gennero, M.-C., Nino, F., Abarca Del Rio, R., Cazenave, A., and Maisongrande, P.: SOLS: A lake database to monitor in the near real time water level and storage variations from remote sensing data, Adv. Space Res., 47, 1497-1507, 2011.

Cristescu, M. E., Adamowicz, S. J., Vaillant, J. J., and Haffner, D. G.: Ancient lakes revisited: from the ecology to the genetics of speciation, Mol. Ecol., 19, 4837-4851, doi:10.1111/j.1365294X.2010.04832.x, 2010.

Dabo-Niang, S., Ferraty, F., and Vieu, P.: On the using of modal curves for radar waveforms classification, Comput. Stat. Data Anal., 51, 4878-4890, 2007.

Davis, C. H.: A robust threshold retracking algorithm for measuring ice-sheet surface elevation change from satellite radar altimeters, IEEE T. Geosci. Remote, 35, 974-979, 1997.

Deng, X. and Featherstone, W. E.: A coastal retracking system for satellite radar altimeter waveforms: Application to ERS-2 around Australia, J. Geophys. Res., 111, C06012, doi:10.1029/2005JC003039, 2006.

De Sa, J. P. M.: Applied Statistics using SPSS, Statistica, MATLAB and R, Springer-Verlag, Berlin, Heidelberg, 2007.

ESA - European Space Agency: Envisat RA2/MWR Product Handbook, European Space Agency, 27 February 2007.

ESA - European Space Agency: Envisat RA-2/MWR Level 2 User Manual, Envisat Altimetry Quality Working Group, Ver. 1.4, 8 September 2011.

Estiaty, L. M., Susilowati, Y., Harsono, E., and Tjiptasamara, T.: Pemodelan Spasial Fluks Polutan pada Sistem Daerah Aliran Sungai dan Angkutan Polutan pada Sistem Sungai, Studi Kasus: DAS Mahakam, Pusat Penelitian Geoteknologi, Lembaga Ilmu Pengetahuan Indonesia, Bandung, Indonesia, 2007.

Fenoglio-Marc, L., Fehlau, M., Ferri, L., Becker, M., Gao, Y., and Vignudelli, S.: Coastal sea surface heights from improved altimeter data in the Mediterranean Sea, Proceedings GGEO2008, IAG Symposia, Springer Verlag, Boston, MA, 2009.

Frappart, F., Do Minh, K., L'Hermitte, J., Cazenave, A., Ramillien, G., Le Toan, T., and Mognard-Campbell, N.: Water volume change in the lower Mekong from satellite altimetry and imagery data, Geophys. J. Int., 167, 570-584, 2006.

Guo, J., Chang, X., Gao, Y., Sun, J., and Hwang, C.: Lake Level Variations Monitored With Satellite Altimetry Waveform Retracking, IEEE J. Select. Top. Appl. Earth Obs. Rem. S., 2, 8086, doi:10.1109/JSTARS.2009.2021673, 2009.

Hehanussa, P. E. and Haryani, G. S.: Morfologi cekungan dan profil suhu Danau Matano dan Danau Poso, Limnotek, 6, 13-23, 1999.

Herdendorf, C. E.: Large Lakes of the World, J. Great Lakes Res., $8,379-412,1982$. 
Hwang, C., Guo, J. Y., Deng, X. L., Hsu, H. Y., and Liu, Y. T.: Coastal gravity anomalies from retracked Geosat/GM altimetry: improvement, limitation and the role of airborne gravity data, J. Geodyn., 80, 204-216, 2006.

Kenney, J. F. and Keeping, E. S.: Mathematics of statistics, in: Mathematics of Statistics, Van Nostrand, http://books.google. com/books?id=UdlLAAAAMAAJ (last access: January 2015), 1947 ,

Koblinsky, C. J., Clarke, R. T., Brenner, C. A., and Frey, H.: Measurement of river water levels with satellite altimetry, Water Resour. Res., 29, 1839-1848, 1993.

Kouraev, A. V., Zakharova, E. A., Samain, O., Mognard, N. M., and Cazenave, A.: Ob' river discharge from TOPEX/Poseidon satellite altimetry (1992-2002), Remote Sens. Environ., 93, 238245, 2004

Kuo, C.-Y. and Kao, H.-C.: Retracked Jason-2 altimetry over small water bodies: case study of Bajhang River, Taiwan, Mar. Geodyn., 34, 382-392, 2011.

Laxon, S.: Sea ice altimeter processing scheme at the EODC, Int. J. Remote Sens., 15, 915-924, doi:10.1080/01431169408954124, 1994.

Lee, H.: Radar altimetry methods for solid earth geodynamics studies, PhD thesis, School of Earth Sciences, The Ohio State University, Columbus, Ohio, 2008.

Legresy, B. and Remy, F.: Altimetric observations of surface characteristics of the Antarctic ice sheet, J. Glaciol., 43, 265-275, 1997.

Li, Y.: Root Mean Square Error, in: Encyclopedia of Research Design, edited by: Salkind, N. J., SAGE Publications Inc., Thousand Oaks, CA, 1288-1289, 2010.

McKinnon, K., Hatta, G., Halim, H., and Mangalik, A.: The Ecology of Kalimantan: Indonesian Borneo, The Ecology of Indonesia Series, Vol. 3, Periplus, Singapore, 1996.

Medina, C. E., Gomez-Enri, J., Alonso, J. J., and Villares, P.: Water level fluctuations derived from ENVISAT Radar Altimeter (RA2) and in-situ measurements in a subtropical waterbody: Lake Izabal (Guatemala), Remote Sens. Environ., 112, 3604-3617, doi:10.1016/j.rse.2008.05.001, 2008.

Meybeck, M., Friedrich, G., Thomas, R., and Chapman, D. (Eds.): Rivers, in: Water Quality Assessments - a Guide to Use of Biota, Sediments and Water in Environmental Monitoring, 2nd Edn., UNESCO/WHO/UNEP. 1992, Taylor and Francis, London, New York, 1996.

Michailovsky, C. I., McEnnis, S., Berry, P. A. M., Smith, R., and Bauer-Gottwein, P.: River monitoring from satellite radar altimetry in the Zambezi River basin, Hydrol. Earth Syst. Sci., 16, 2181-2192, doi:10.5194/hess-16-2181-2012, 2012.

Morris, C. S. and Gill, S. K.: Evaluation of the TOPEX/POSEIDON altimeter system over the Great Lakes, J. Geophys. Res., 99, 24527-24539, 1994.

Munyaneza, O., Wali, U. G., Uhlenbrook, S., and Maskey, S., and McArd, J. M.: Water level monitoring using radar remote sensing data: Application to Lake Kivu, central Africa, Phys. Chem. Earth P. A/B/C, 34, 722-728, doi:10.1016/j.pce.2009.06.008, 2009.
Nagler, J.: Root Mean Square, in: The SAGE Encyclopedia of Social Science Research Methods, edited by: Lewis-Beck, M. S., Bryman, A., and Liao, T. F., SAGE Publications, Inc., Thousand Oaks, CA, 978-979, doi:10.4135/9781412950589.n871, 2004.

Panik, M. J.: Statistical Inference: a Short Course, John Wiley \& Sons, Hoboken, 2012.

Rees, G.: Physical Principles of Remote Sensing, Cambridge University Press, Cambridge, England, 1990.

Russel, J. and Bijaksana, S.: The Towuti Drilling Project: paleoenvironments, biological evolution, and geomicrobiology of a tropical lake, Scient. Drilling, 14, 68-71, doi:10.2204/iodp.sd.14.11.2012, 2012.

Sarmiento, S. E. and Khan, S. D.: Spatial-Temporal Variability of Great Slave Lake Levels From Satellite Altimetry, IEEE Geosci. Remote Sens. Lett., 7, 426-429, doi:10.1109/LGRS.2009.2038178, 2010.

Tang, Q., Gao, H., Lu, H., and Lettenmaier, D.: Remote sensing: hydrology, Prog. Phys. Geogr., 33, 490-509, 2009.

Torrance, K. E. and Sparrow, E. M.: Theory for Off-Specular Reflection From Roughened Surfaces J. Opt. Soc. Am., 57, 11051112, doi:10.1364/JOSA.57.001105, 1967.

Troitskaya, Y. I., Rybushkina, G. V., Soustova, I. A., Balandina, G. N., Lebedev, S. A., Kostyanoi, A. G., Panyutin, A. A., and Filina, L. V.: Satellite altimetry of inland water bodies, Water Resour., 39, 184-199, doi:10.1134/S009780781202008X, 2012.

Tseng, K.-H.: Satellite Altimetry and Radiometry for Inland Hydrology, Coastal Sea-Level and Environmental Studies, School of Earth Sciences, The Ohio State University, Columbus, Ohio, 2012.

Tseng, K.-H., Shum, C. K., Yi, Y., Fok, H. S., Kuo, C.-Y., Lee, H., Cheng, X., and Wang, X.: Envisat Altimetry Radar Waveform Retracking of Quasi-Specular Echoes over the IceCovered Qinghai Lake, Terr. Atmos. Ocean. Sci., 24, 615-627, doi:10.3319/TAO.2012.12.03.01(TibXS), 2013.

Vaillant, J. J., Haffner, G. D., and Cristescu, M. E.: The Ancient Lakes of Indonesia: towards Integrated Research on Speciation, Integr. Comp. Biol., 51, 634-643, 2011.

Wingham, D. J. and Rapley, C. G.: Saturation effects in the Seasat altimeter receiver, Int. J. Remote Sens., 8, 1163-1173, 1987.

Wingham, D. J., Rapley, C. G., and Griffiths, H. G.: New techniques in satellite altimeter tracking systems, III IGARRS 1986 Symposium, Zurich, Proceedings, Noordwijk, ESTEC, Scientific and Technical Publications Branch, ESA SP-254, 1339-1344, 1986.

Zhang, J., Xu, K., Yang, Y., Qi, L., Hayashi, S. and Watanabe, M.: Measuring Water Storage Fluctuations in Lake Dongting, China, by Topex/Poseidon Satellite Altimetry, Environ. Monitor. Assess., 115, 23-37, doi:10.1007/s10661-006-5233-9, 2006.

Zwally, H. J.: The GSFC Retracking Algorithms, NASA Goddard Space Flight Center, Cryospheric Sciences Laboratory, http://icesat4.gsfc.nasa.gov/radar_data/data_processing/ gsfcretrackdoc.960725.php (last access: January 2015), 1996. 